\title{
The contributions of Dr Raymond Wilkie Brougham to grassland science and management
}

WARWICK HARRIS

Landcare Research, PO Box 69, Lincoln, Canterbury, New Zealand

\section{Summary}

The contributions to grasslands research and practice of the internationally notable New Zealand Scientist, Dr Raymond Wilkie Brougham are reviewed. He made significant contributions to the fundamental understanding of processes in pasture establishment, pasture growth particularly its relationship with leaf area and light interception, and to grazing management effects on the botanical and genetic composition of grassland communities.

Application of his understanding of the requirements of pasture management was demonstrated in a series of farmlet studies that realised very high levels of dairy beef production. In New Zealand, and internationally later in his career, he was very successful in transferring his concepts of management to grasslands farmers. In retirement he made very important contributions to the New Zealand amenity and sports turf industry.

He played a very significant administrative role in shaping the direction of grassland research and application in New Zealand, especially when Director of Grassland Division from 1971' tō 1985. His concepts of organisational structures that met both national and regional needs for research and extension were applied worldwide in his role as an international consultant. As President of the XVII International Grassland Congress he led the development of a conference format that encouraged participation for effective presentation and discussion of grassland research and application.

Keywordstlight-interception, pasture composition, pasture establishment, research administration

\section{Introduction}

As one of many people helped by Dr Ray Brougham (Figure 1) in their involvements with the development and use of grasslands I am privileged to accept the request from PASTOS* to write a review of his work. Inevitably my review will draw most intensively on the period from 1959 to 1982 when I worked closely with him as a research worker in pasture ecology. Others who worked with him at other places, at other times, and in ways different from those that were the basis of my association, Figure 1 Dr Ray Brougham. would bring in d iffere $\mathrm{nt}$ perspectives and introduce other aspects of his works with which I am not familiar. My review draws most directly on his published works. The bibliography contains the most comprehensive

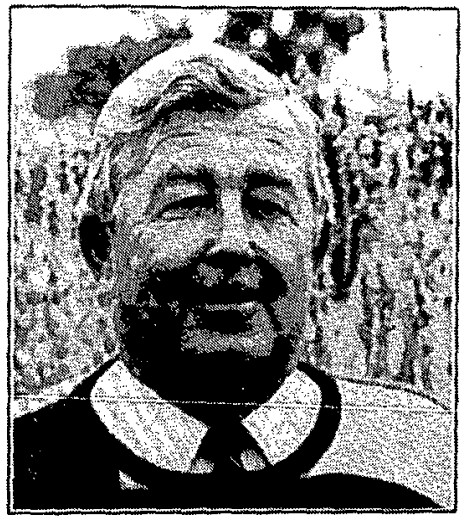
listing of these publications that I have been able to compile. Not all of the publications are referred to in the text, but they are listed to illustrate the extent to which Ray Brougham made the effort to present, interpret and discuss the practical applications of his results to grassland farmers, advisors and research workers. The figures chosen to illustrate his research results are copied without alteration -from-the-original-publications.-Although-these ___ mostly use imperial measurements, it is the relative rather than the absolute differences of the responses observed in his experiments that are of most interest. One of Ray Brougham's strengths was the ability and willingness to communicate with people at the individual level both orally and by letter. Undoubtably a wealth of information and wisdom rests in these communications. I hope this review will act as an encouragement to those whose work on grasslands was influenced by Ray Brougham to record their associations with him and pass these records on to the grassland workers of the future:--

The early years

Ray Brougham was born in Palmerston North in 1926 and remained a loyal citizen of that city until he died on 24 October 1993. Palmerston North is situated in the south western part of the North Island of New Zealand

* The NZGA would like to thank Sociedad Espariola para el Estudio de los Pastos for permission to reprint this paper, first published in Revista PASTOS XXIII (2), pp. 3-51 (1993). 
in an environment that is regarded as one of the most favourable for pasture production in the'world. The city developed as a servicing centre for the dairy, cattle and sheep farms on the productive pastures of the formerly forested plains and hill country of the Manawatu region.

Development in the 1920s of two institutions that have been of key significance to agricultural research in New Zealand raised the status of Palmerston North above that of many other New Zealand towns and cities that developed as rural servicing centres. These institutions provided the opportunity for the career path that Brougham followed, and he became a leading advocate of their roles later in his life. They were Massey Agricultural College founded at Palmerston North in 1926, and the New Zealand Department of Scientific and Industrial Research (DSIR) established in the same year. In 1928 a Plant Research Station was established in Palmerston North as a joint undertaking of the New Zealand Department of Agriculture and DSIR. This organisation formed the foundation of several DSIR Divisions, including Grasslands Division. Grasslands Division retained its headquarters in Palmerston North when it was established in 1936 with Sir E. Bruce Levy as the first Director (Atkinson 1976). Massey Agricultural College, now Massey University, and Grasslands Division which was incorporated as part of the Agresearch Crown Research Institute in 1992, gave Palmerston North international status as a centre of excellence in grassland research.

Brougham's entry into grasslands research was by chance. He completed his secondary school education at Palmerston North Boys' High School and was successful in gaining entry for officer training at' the Military College, Duntroon, Australia but did not take this up. He worked as a clerk at the local power board in 1945. It was during this time that an encounter at a vehicle service station in Palmerston North between his father and Dr Peter Sears, then Head of the Pasture Ecology Section of Grasslands Division, provided the opportunity for Brougham's entry in to grasslands research as cadet/technical assistant in February 1946. He was supported for study at Canterbury University College and graduated with a B.Sc. from the University of New Zealand in 1950. In 1963 he was awarded the degree of D.Sc. by Canterbury University.

Both Levy and Sears were key influences on the development of Brougham's ideas and philosophy about grassland ecology and production. Levy's broad understanding of grassland ecology, presented in his book "Grasslands of New Zealand" (Levy 1970), still stands as an authoritative integrated account of New Zealand's grassland ecology and production. It was from Sears and those that worked on his studies of pasture growth and soil fertility (Sears 1953a, b, c: Melville \& Sears 1953, Sears \& Evans 1953) that Brougham would have learned about the practical aspects of grassland experimentation and the fundamental function of nitrogen fixation by clovers in New Zealand pastures. It is in this series of studies that the name R.W. Brougham first appears in the grassland science literature in an acknowledgement for technical assistance.

\section{Pasture establishment studies}

Two important factors influencing the requirements for research on pasture establishment in New Zealand after the Second World War were the expansion of intensive grassland development into areas with climates and soils more marginal for pasture production, and the availability of new herbage cultivars. An important facet of Sears work was pasture establishment on the pumice soils of the central volcanic plateau of the North Island (Sears et al. 1955). At about the same time as Sears' study Brougham began experimentation in his own right by undertaking studies that focused on the use of shortrotation ryegrass in the establishment of pasture on the fertile soils of the Grasslands Division research station at Palmerston North.

Short rotation ryegrass, (Lolium perenne $X \mathbf{L}$. multiflorum) also known as $\mathrm{H} 1$ ryegrass and later as 'Grasslands Manawa', marked a significant step in the the progress of forage plant breeding in New Zealand. It was bred by Dr Lionel Corkill (1945), who became Director of Grasslands Division when Sears died in 1963, and continued in this role until his retirement in 1971 when Brougham was appointed Director. An important function of the Pasture Ecology Section, of which Brougham was a member, was to evaluate and introduce new herbage cultivars into grazing management systems. This could be done as a routine agronomic evaluation. However I surmise that in being given the task of evaluating short-rotation ryegrass, Brougham was motivated more by gaining insight of the mechanisms that caused the cultivar to perform in a particular way, rather than just recording that performance.

The results of these pasture establishment studies were first reported at the first of Brougham's many appearances on the platform of the annual conferences of the New Zealand Grassland Association when the fourteenth of these conferences was held at Timaru in 1952 (Brougham 1953). Dr Ken Mitchell and Mr Arch Glenday, both of whom had a marked influence on his work, also spoke at this conference (Glenday 1953; Mitchell 1953). Insights gained by Mitchell through study of the whole plant physiology of pasture grasses and clover were important in the interpretation of the results Brougham gained from his field experiments, and Glenday played a key role in the design and statistical analysis of the experiments he undertook. 
Figure 2 Effects of short-rotation ryegrass seeding rate on total and ryegrass and clover yield for the establishment year of a pasture (Brougham 1954a).

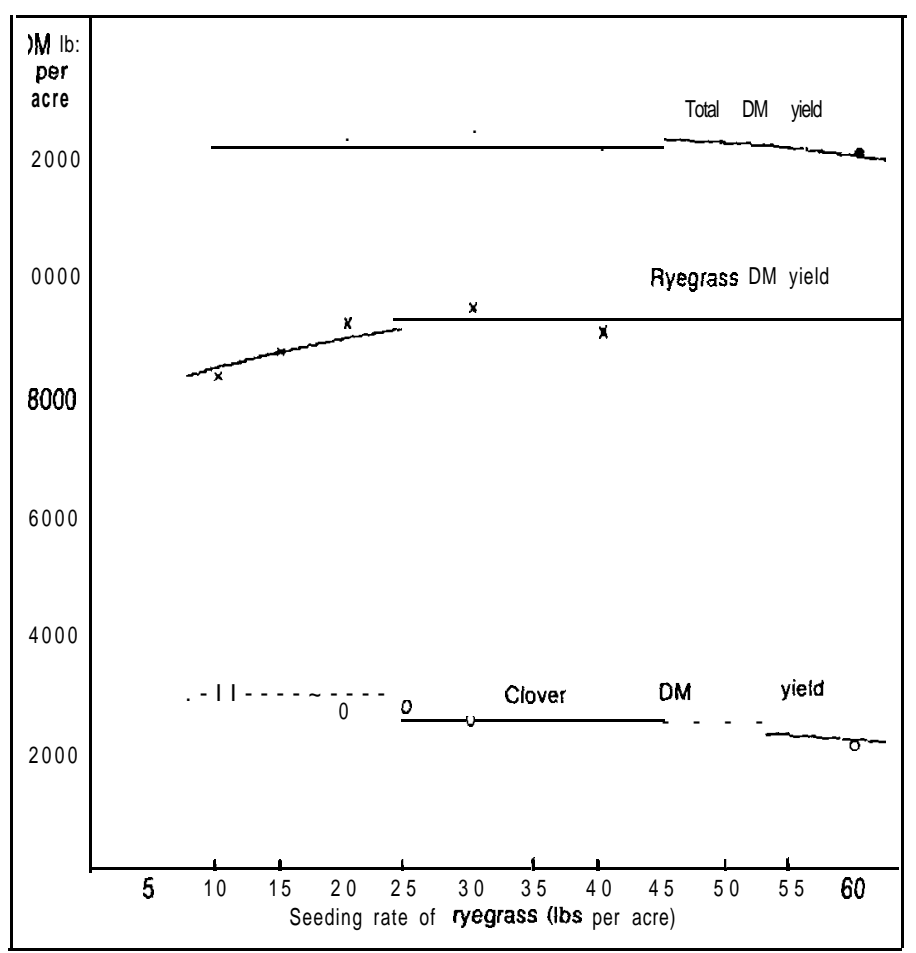

The-pasture establishment studies, published as'a series of four papers in 1954, contributed-to-what continue to be standards for the formulation of the seed rates and species proportions for high producing ryegrass-white clover pastures in New Zealand. The first study (Brougham 1954a) measured changes of seedling populations, effects on plant development of the grass and clover components, and herbage yields for the year following autumn sowing when the seeding rate of short-rotation ryegrass was varied in seven steps from 0 to $67 \mathrm{~kg} / \mathrm{ha}$, while the rates of red clover (Trifolium-pratense) and white clover (T. repens) were held constant at 4.5 and $3.4 \mathrm{~kg} /$ ha respectively. $\mathrm{High}^{-}$ short-rotation seed rates provided more ryegrass and total yield initially but suppressed clover yield. This reduced clover yield resulted in a reduction of nitrogen available to the grass, reducing ryegrass yield at higher seeding rates later in the year. Consequently for the year the optimum result in terms of seed cost, grassclover balance, weed control and yield was obtained with a short-rotation seed rate of about $20 \mathrm{~kg} / \mathrm{ha}$ (Figure 2). The study showed the compensating effects caused by competition for light of tiller number per established seedling and tiller weight on the unit area yield of the pasture.
The second experiment (Brougham 1954b) investigated grazing height as a management option in the establishment of short rotation ryegrass-clover pasture. Short rotation ryegrass sown in aưfumn with red and white clover at rates of 17 or $45 \mathrm{~kg} / \mathrm{ha}$ was initially grazed when the pasture height reached either 7.5 or 22.5 $\mathrm{cm}$. Later these grazing heights were reversed. Grazing at a herbage height of $7.5 \mathrm{~cm}$ enabled good clover establishment irrespective of grazing height whereas clover growth was suppressed to the extent that it caused unthrifty ryegrass growth in spring with the combination of high ryegrass seed rate and grazing at $22.5 \mathrm{~cm}$. Brougham concluded that sowing short-rotation ryegrass at the low seed rate was advantageous as it allowed more latitude in the grazing management used without adversely affecting clover establishment.

Effects on short-rotation ryegrass and clovers by the inclusion of barley as a cover crop for winter green feed was investigated in a third experiment (Brougham 1954c). While barley boosted winter yield, its inclusion in the seeds mixture depressed ryegrass and total yield but increased clover in spring. However by summer the -effects of barley were not apparent. These responses were explained by reference to grazing height-effects.on. competition for light and effects of clover suppression on available soil nitrogen. The fourth experiment (Brougham 1954d) examined interactions between the components of what became a standard mixture for medium to longterm pastures on fertile soils from the 1950s through to the 1970s - 'Grasslands Ruanui' perennial ryegrass, 'Grasslands Manawa' short-rotation ryegrass and red and white clover. This study showed that short rotation was more aggressive than perennial ryegrass during the establishment phase causing suppression of both weeds and clovers. It pointed to the need to define the appropriate balance between the content of the two ryegrasses in mixtures and was the forerunner to experiments that followed changes in the genotypic structure of ryegrass based pastures.

\section{Pasture growth rate studies}

In 1953 Brougham began a series of intensive studies of the growth of short-rotation ryegrass and clover pasture, collecting data to construct the curves of herbage dry matter production after defoliation. The first of these 
studies (Brougham 1955) obtained curves for total herbage and ryegrass growth in spring that were sigmoid with three phases over the nine-week growth periods. The second linear phase provided a constant daily increment of dry matter of about $170 \mathrm{~kg} / \mathrm{ha}$ for about five weeks. This result led to the suggestion that maximum herbage production from the pasture could be maintained if herbage height was kept in the range that occurred during the five-week period i.e., 12.5 to $35 \mathrm{~cm}$.

Brougham next directed attention to the growth of short-rotation ryegrass-based pasture over the late autumn to early spring period (Brougham 1956a). This study related to the practice of in situ conservation by spelling pasture in autumn to allow the saving of herbage to be fed to stock during the period of low pasture growth in winter and early spring. The experiment measured the accumulation of herbage from four commencement dates of spelling at three-week intervals, starting from 1 April (12 weeks before the winter solstice). Apart from the last spelling period the growth curves were sigmoid (Figure 3). The initial phase of growth became extended from about 5 to 10 weeks as the commencement of spelling was delayed into the winter. For the first three spelling dates the second linear phase lasted about three weeks but the growth rate decreased as the spelling date was delayed. Consequently the highest ceiling yield was obtained from the first spelling date. This treatment provided little further yield after nine weeks whereas the treatment spelled from this date yielded $1350 \mathrm{~kg}$ DM during the 9 th to 18 th week. From these results Brougham concluded that maximum yield during the 16 weeks of the late autumn to early spring would be obtained with spelling intervals no longer than six weeks. Less intensive defoliation by grazing during this period was also recommended as a way to reduce the length of the initial growth phase.

\section{Effects of season and weather on pasture production}

The technique Brougham used in his pasture growth studies was developed in collaboration with Glenday (1955,
1959) and involved layouts that provided replication in time as well as space to allow separation of temporary weather variations on growth. This enabled derivation of pasture growth curves with the influence of shortterm weather fluctuations removed. The approach was also used to identify the importance of the specific effects of light levels, temperature and rainfall on pasture growth rates.

Brougham (1959a) using the technique derived a set of annual growth curves of a short-rotation and white clover pasture (Figure 4). The average daily growth rate of the pasture ranged from $10 \mathrm{~kg} \mathrm{DM} / \mathrm{ha}$ in winter to $135 \mathrm{~kg} \mathrm{DM} / \mathrm{ha}$ in early summer. It was estimated that the potential annual yield of the pasture on the fertile soil of the site was $24,000 \mathrm{~kg} \mathrm{DM} / \mathrm{ha}$ (Figure 5). This yield became a bench mark to measure progress in improvement of pasture production in New Zealand and to explain the losses of yield caused by factors such as treading and summer drought. The study

Figure 3 Fitted logistic regrowth curves for the dry matter yields for total herbage and ryegrass yields from four dates of spelling in autumn and winter with associated variation of mean weekly air temperatures and rainfall totals (Brougham 1956a).

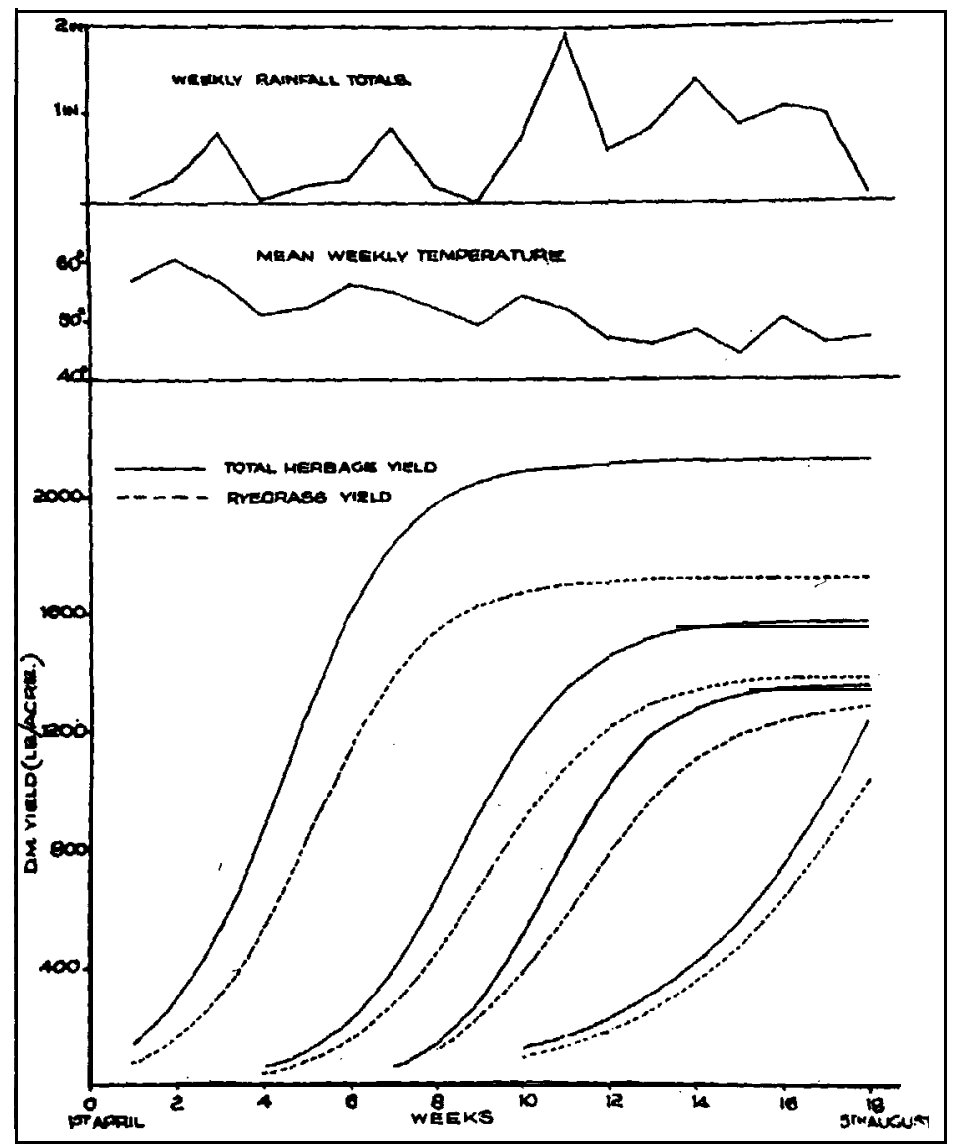


also highlighted the seasonal switch from ryegrass to white clover dominance. In discussing this switch, Brougham probably underestimated although did not overlook the importance of flowering in causing the reduction of short-rotation ryegrass growth in summer. Defoliation in relation to both its impact on leaf area index and light interception and reproductive growth was an important subject of later detailed sward studies aspects of which are reviewed by Korte \& Harris (1987). Brougham's (1959a) study showed that in winter the growth of the dominant ryegrass component was influenced by both temperature and light levels, whereas in summer fluctuations of white clover growth were mainly associated with temperature variation.

A related study examined the effects of weather fluctuations on the daily rate of growth of pure stands of perennial and short-rotation ryegrass and cocksfoot (Brougham \& Glenday 1969). The marked differences of seasonal growth rates recorded were attributed to seasonal changes of temperature and light, and variation of summer rainfall. Effects of daily changes of weather on pasture growth were also detected, in some cases showing timelag correlations.

The untimely death of Arch Glenday before publication of this work deprived Ray Brougham of a person who was a very important aide in his experimental work. Glenday was an excellent and patient teacher and applicator of biometrics and statistics at a time before modern computer technologies removed most of the drudgery of applying these disciplines to experimental work.

Leaf area, light interception and chlorophyll content

Detailed examination of the effects of intensity of defoliation on pasture regrowth was made in an experiment undertaken in spring 1954 (Brougham

Figure 4 Ryegrass and clover yields separated into growth curves for a smoothly changing climate from a series of defoliation dates in the course of a year at Palmerston North, New Zealand. The'weather parameters show growth attributable to weekly fluctuations in weather (Brougham 1959a).

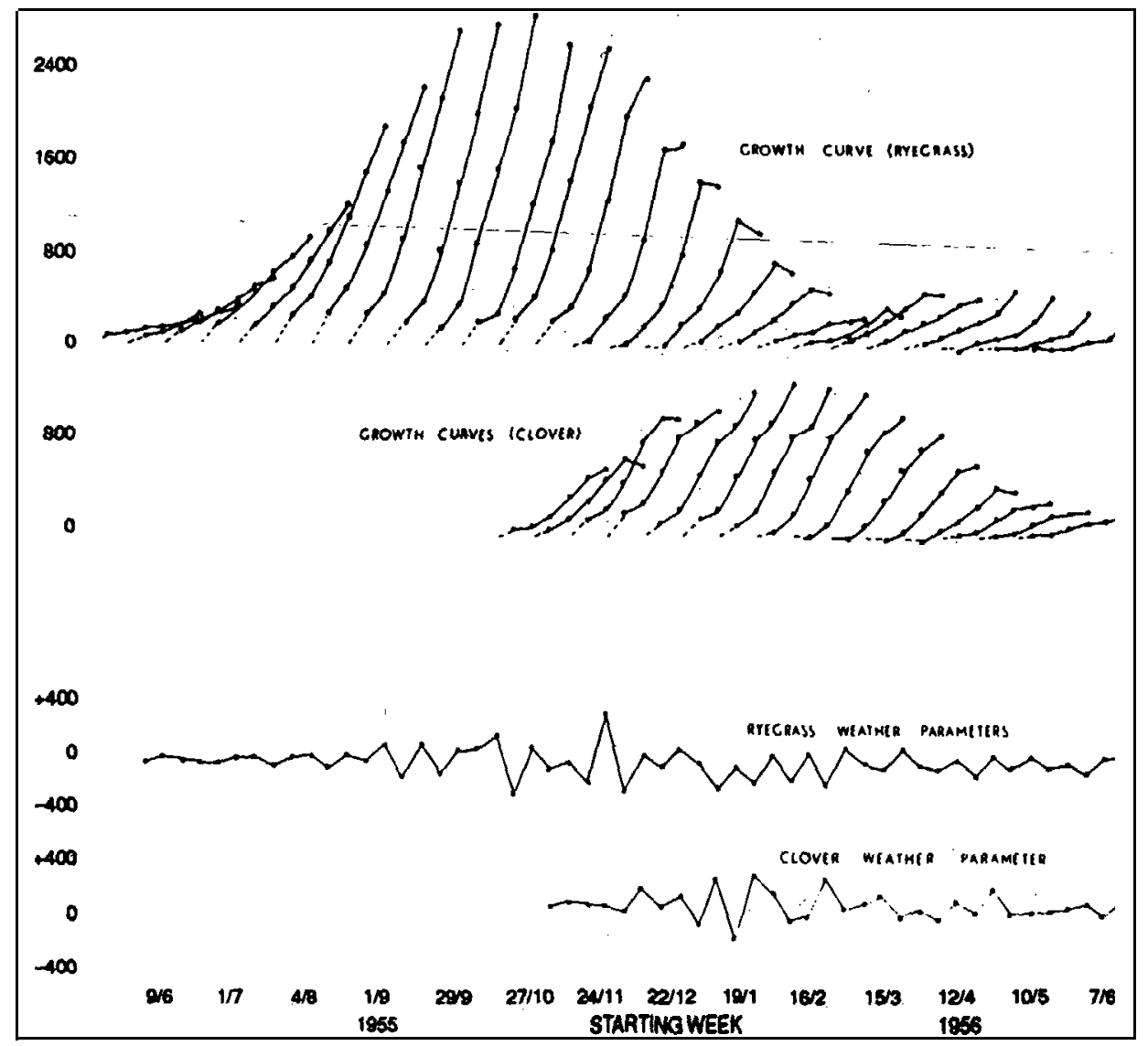


Figure 5 Increments of total herbage, ryegrass and clover dry matter for the third and fourth weeks of pasture regrowth from a time series of dcfoliations in the course of a year at Palmerston North, New Zealand. Standard errors relate to total" yield.

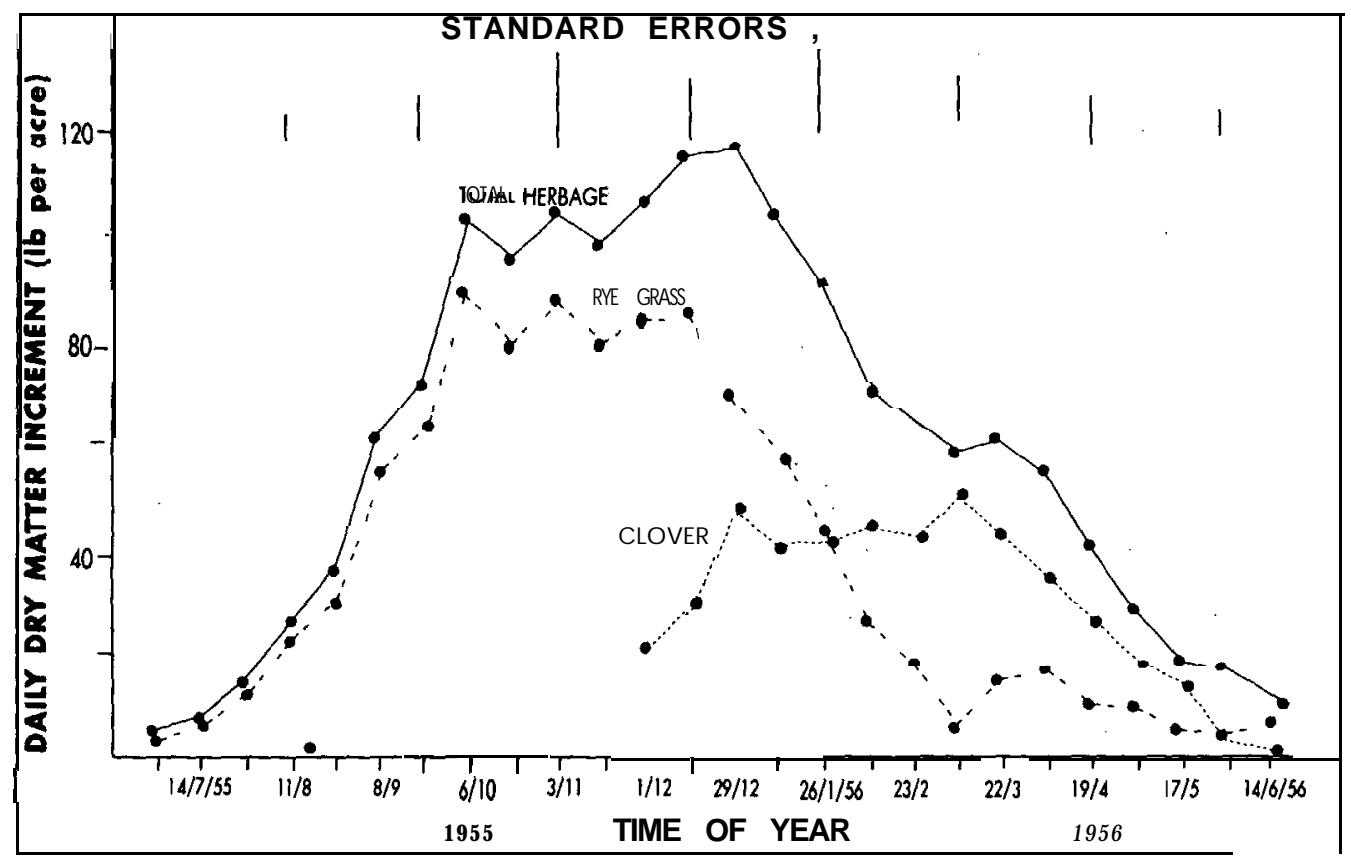

1956b). Short-rotation and clover pasture was cut back from $23 \mathrm{~cm}$ to heights of 2.5 , 7.5 and $12.5 \mathrm{~cm}$ and the regrowth of these treatments measured for 32 days. Changes of leaf area and light interception that occurred during the regrowth of the treatments weie also recorded. This was the first time that the relationships between light interception, leaf area and the rate of regrowth were studied for pasture. Full light interception was attained when the area of leaf of the pasture per unit area of ground (leaf area index) reached 5 (Figure 6) and it was at this stage of regrowth' that the maximum daily rate of herbage accumulation was reached (Figure 7). Differences between the cutting heights in the efficiency of leaf to provide herbage dry matter increases were demonstrated, but the more important effect was the period taken by the cutting heights to
Figure 6 The relationship between the percentage interception of incident light by the leaf area of ryegrass-clover pasture defoliated to three heights (Brougham 1956b).

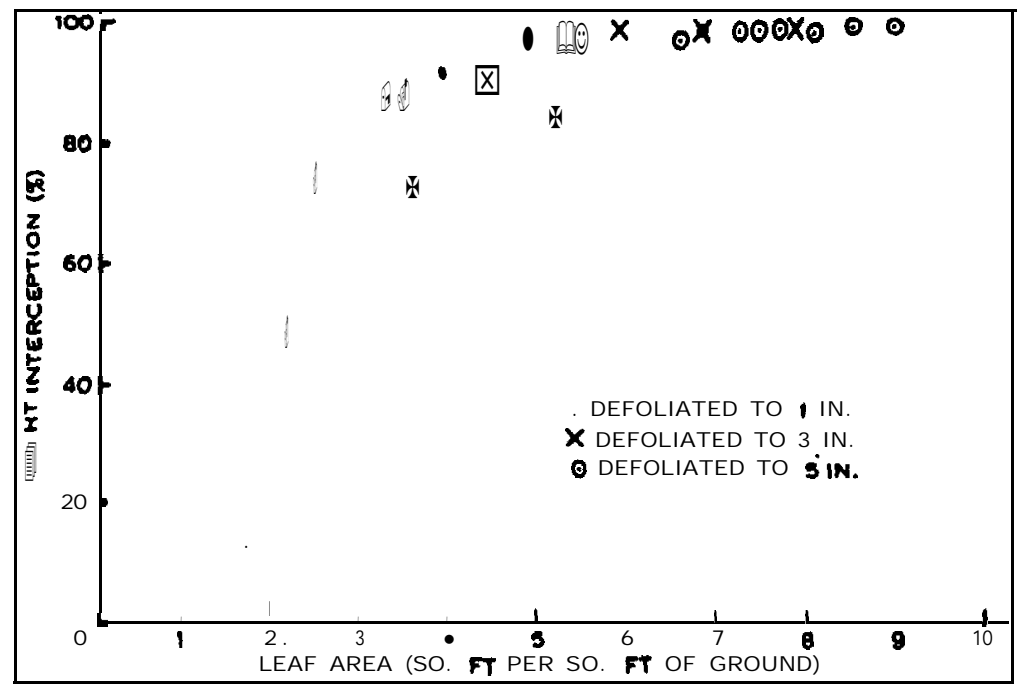

reach $95 \%$ light interception. This took 24 and $\mathbf{1 6}$ days for cutting to 2.5 and $7.5 \mathrm{~cm}$ respectively, whereas the leaf left after cutting to $12.5 \mathrm{~cm}$ was sufficient to intercept most of the light (Figure 8). Consequently 
drymatter increments were highest for the most leniently defoliated treatment (Figure 9). This finding supported the conclusion that, for maximum production of herbage, the amount of leaf left after defoliation by grazing or mowing should be sufficient to ensure complete interception of light. Grazing using the $95 \%$ light interception criterion became a maxim in Brougham's extension of his findings to the management of pastures by grasslands farmers. However, as will be seen from his later studies, this criterion was to be qualified according to season and other factors.

In extending light interception studies to pastures composed of different species Brougham (1958a) found that in midsummer at midday the leaf area indices at which $95 \%$ of the incident light was intercepted differed considerably. These leaf area indices were: short- -rotation--ryegrass; - -7.1;- perennial ryegrass (Lolium perenne) 7.1 ; timothy (Phleum pratense) 6.5; white clover (3.5); and short-rotation ryegrass and white clover mixture 4.5 (Figure 10). Changes in the leaf area index intercepting $95 \%$ of incident light in the course of a day and during different seasons wiêre alsomeasured. The different light intercepting characteristics of the grasses and white clover were explained by their different leaf arrangements. The horizontal leaves of white clover directly intercept more light than the long slender, largely erect leaves of the grasses that allow light to penetrate and to be reflected further into the pasture canopy. Brougham concluded that in order to most effectively utilize available light to maximize pasture growth herbage, height at commencement of grazing and the amount left after grazing would be appreciably
Figure 7 The relationship between herbage dry matter increment and the leaf area of ryegrassclover pasture defoliated to three heights (Brougham 1956b).

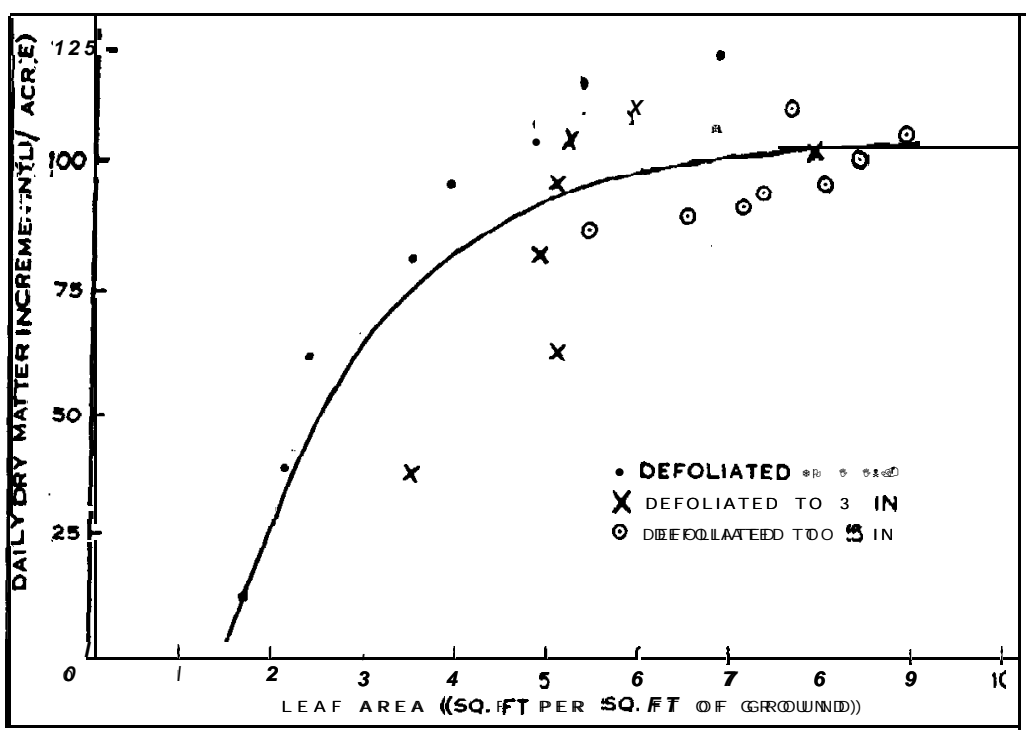

Figure 8 Changes of percentage interception of incident light in the course of the growth of ryegrass-clover pasture defoliated to three heights (Brougham 1956b).

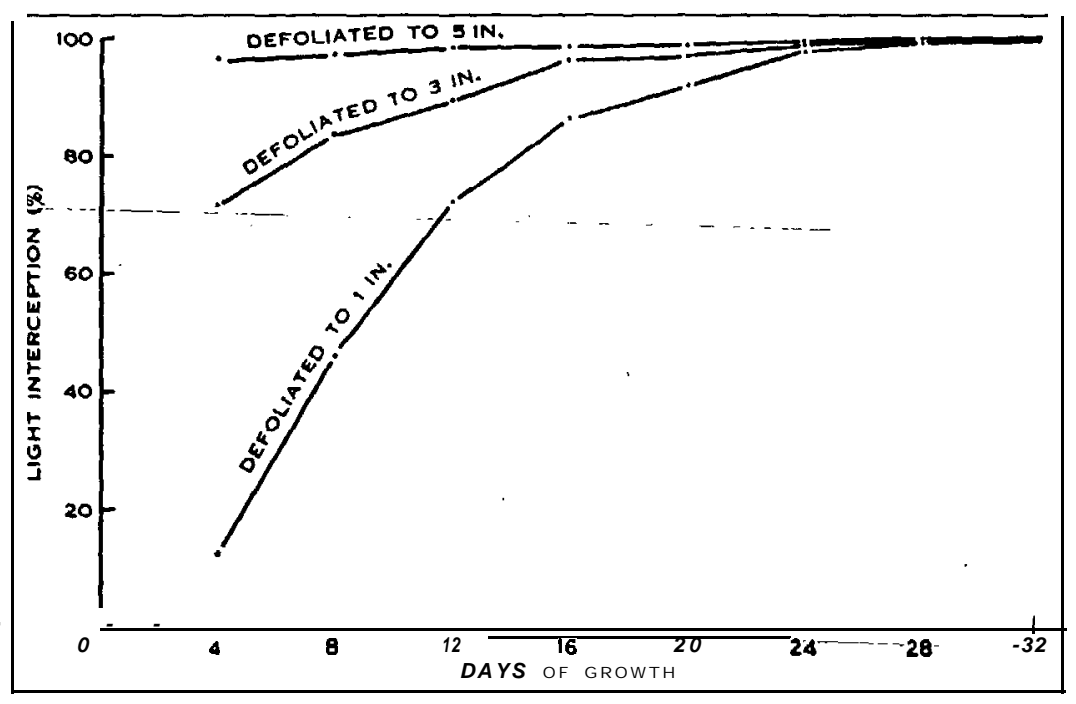

lower in winter than in summer. Keeping pasture shorter during winter would also have the advantage of lowering pasture losses by reducing plant tissue decomposition. White clover would produce at its maximum rate under closer grazing than grass, and for grass-clover mixtures the recommendation was that the grazing height should be determined by reference to the light-intercepting characteristic of the dominant species component. 
The relationships between leaf area index and growth rate were extended to a consideration of how these related to the chlorophyll content of the leaf area intercepting $95 \%$ of incident light (Brougham 1960c). A highly significant correlation was found between the maximum growth rates of the eight species studied and their chlorophyll content. However growth rate proportional to the amount of chlorophyll was found to be higher for red and white clover, kale and maize which have horizontal or distinctly flagging leaves compared to the erect leaved perennial and short-rotation ryegrasses. This differences was attributed to either differences in the efficiency or activity of chlorophyll between the two groups of species or to greater partitioning of drymatter to the underground organs of the erect-leaved grasses.

Anslow (1965) concluded from results of an experiment conducted at the Grassland Research Institute, Hurley, England, that there was no significant relationship between leaf area index, light interception and growth rate of a perennial ryegrass sward in mid-summer. He emphsised his conclusion further by stating that higher growth rates would not be obtained by paying attention to the relationship between light interception and leaf area index. Brougham \& Glenday (1967) reexamined Anslow's

data to show the sigmoid form of the regrowth curves and a well defined linear relationship between leaf area index and yield.

This was the beginning of long running and still unresolved differences of opinion about the advantages of rotational grazing systems particularly as such systems relate to manipulation of the light intercepting 1956b).
Figure 9 Growth curves of ryegrass-clover pasture defoliated to three heights (Brougham

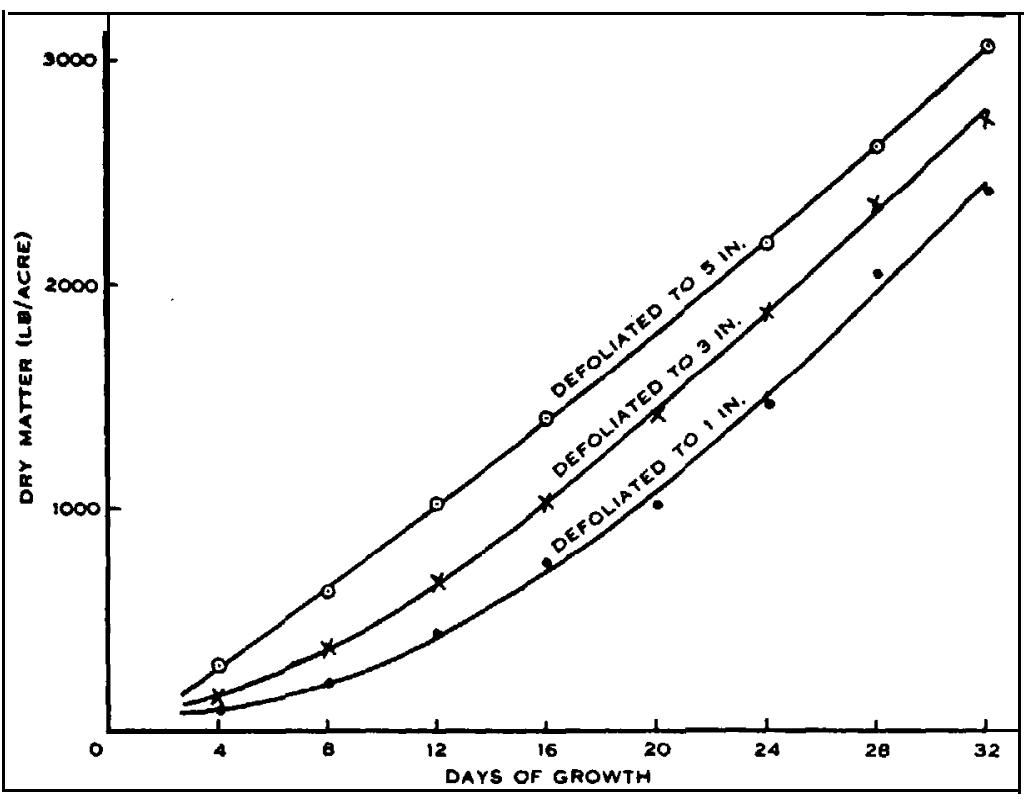

Figure 10 The relationship between light interception and leaf area for three single species and ryegrass-clover pasture (Brougham 1958a).

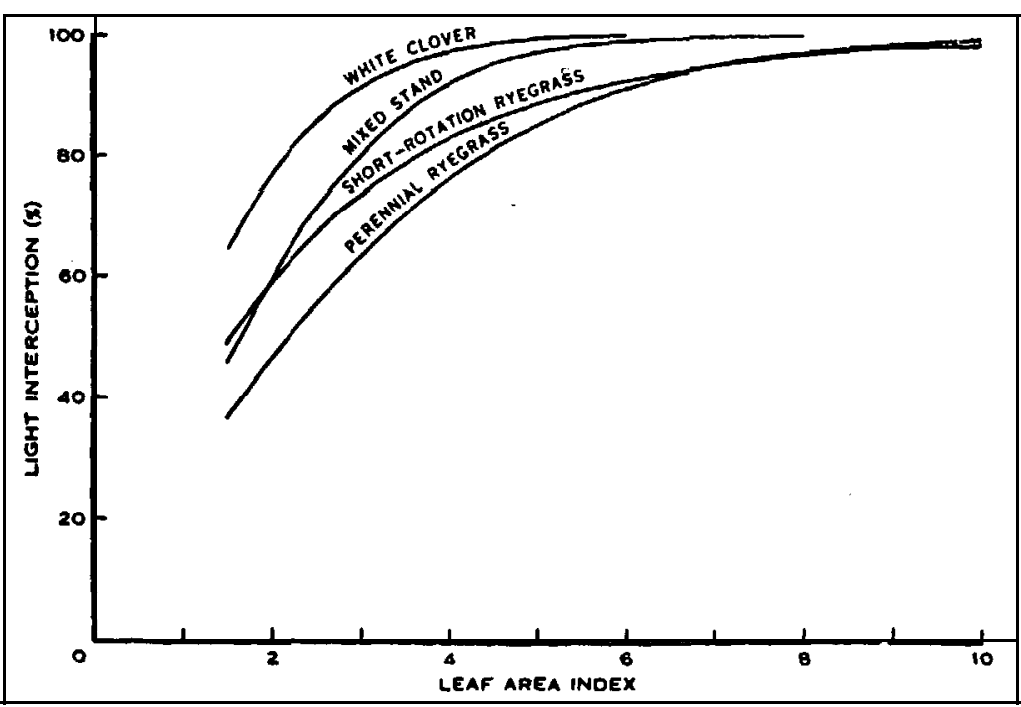

characteristics of pasture. Putting aside the effects of grazing animals on pasture, I venture that much of the opinion that came out of the British Isles which was contrary to Brougham's emphasis about the importance of leaf area index and light interception and pasture growth did not take in to account key differences between New Zealand and British grassland systems. In New Zealand 
year-round grazing is the universal practice whereas in much of the British Isles stock are removed from pasture for a considerable period during the cold months of the year. This in itself introduces a significant element of rotational grazing into British grazing systems. In New Zealand, management of grazing over autumn and winter has to take into account the continuity of supply of adequate levels of herbage for livestock requirements, at the same time ensuring that botanical composition and photosynthetic capacity of the sward gives the most favourable growth response to seasonal environmental conditions.

Climatic differences also mean that the period of reproductive growth of ryegrasses is more concentrated and intense in the British Isles than in New Zealand. Consequently changes in biomass partitioning associated with flowering have a more dominating influence on the relationships between leaf area index and light interception than is the case in the lower latitudes where New Zealand lies. Leafe et al. (1974) gave a good account of the interacting factors that regulate pasture yields in spring in England - increasing levels of radiation in spring allows levels of optimum leaf area index and ceiling yield to advance progressively; partitioning of more assimilates to shoots than to roots increases harvest index; and stem extension promoted by reproductive growth results in new leaves emerging and developing higher in the sward where there is more light. Also, the climatic restriction of pasture production in the British Isles does not allow the clear separation of seasonal dominance of pasture spēies characteristic of -New-Zealand-pastures.as clearly shown in the study of season and weather on the growth of ryegrass-clover pasture (Brougham 1959a; Figure 5). As shown by the progression of ideas tested in his experimental work, Brougham included strategic grazing both to bring about seasonal changes of species dominance and to condition the photosynthetic efficiency of swards in the grazing systems he promoted.

Brougham's ongoing interest in more detailed studies of light relations in pastures is indicated by his involvement in a study of the spectral analysis of radiation transmitted and reflected by 16 contrasting vegetation types (Scott et al. 1968). During my involvement with him as technical assistant in his chlorophyll work he discussed the possibility of undertaking a study in a locality with distinctly different levels of incident radiation. Fiji was mentioned as a very suitable locality but we did not manage to get there. However his career path was to take him away from more detailed fundamental studies. Instead, as much as his administrative responsibilities allowed, he concentrated more on demonstrating the practical applications of his fundamental understanding of light relations in pastures and how this could be manipulated to optimise pasture production. He continued to be very supportive of those engaged in more fundamental aspects of pasture research, mindful as a result of his own experience of the linkages between research at this level and progress in applied grassland farming technology.

\section{Effects of grazing frequency and intensity}

From the basis of understanding gained from his cutting experiment studies of factors regulating pasture growth rate, Brougham (1959b) initiated experiments investigating the effects of frequency and intensity of grazing with sheep on the productivity of short-rotation ryegrass and clover pasture. With reference to the growth curves of this pasture type (Brougham 1955, 1956b) four grazing treatments were applied. These were grazing from: $8-10$ to $2.5 \mathrm{~cm}$ (frequent-hard); $15-23$ to $2.5 \mathrm{~cm}$ (infrequent-hard); $18-20$ to $8-10 \mathrm{~cm}$ (frequent-lax); and 23-30 to $8-10 \mathrm{~cm}$ (infrequent-lax). The last two treatments aimed to leave a considerable amount of green tissue after grazing, whereas for the first two most of the photosynthetic tissue was removed with a contrast of different lengths of spelling between grazing. These treatments were continued for two years and the yield of herbage removed by grazing, botanical composition, ryegrass tiller numbers and soil-moisture levels measured. It was found that annual herbage production was highest under infrequent grazing, was also high under frequent-lax grazing, but was reduced by hard grazing. These treatments had distinctive effects on -yields-of-t\&species with - short-rotation ryegrass favoured by infrequent grazing, red clover by lax grazing and white clover by frequent grazing. Seasonal effects on the impact of the grazing treatments were observed with the performance of short-rotation ryegrass being especially impaired by hard grazing in late summer and autumn, whereas hard grazing provided more yield in winter. This winter effect was attributed to the lower level of foliage left after grazing required to intercept incident light, and the reduction of herbage losses from decomposition. Longer term effects of hard grazing on -the-persisteney-of-short=rotation_ryegrass were also observed. The final concluding remark of the paper, that there was a need for wide-scale field experiments covering both pasture and animal productivity reactions to differential frequencies and intensities of grazing, points to the direction of his later experimental and administrative work.

Effects of frequent-hard grazing in different seasons on the productivity and botanical composition of a shortrotation tyegrass, cocksfoot (Dactylis glomerata), red and white clover were studied in an experiment (Brougham 1960a) that overlapped the experiment just described. Six grazing treatments were applied for a year: 
frequent-hard all year; frequent-lax all year; and frequentlax with periods of hard grazing in winter, spring, summer or autumn. This was followed by six months frequent-lax grazing of all treatments. Two key facets of grazing management were highlighted by this study and these were the subjects of subsequent detailed studies. First was the susceptibility of all the species except white clover to hard grazing in summer that caused a longerterm reduction of pasture production. Secondly was the usefulness of hard grazing in autumn to bring a switch from the summer dominance of the clovers and cocksfoot to ryegrass with its capacity for higher winter growth rates.

\section{Detailed studies of white clover swards}

In spring 1957 Brougham embarked on a series of intensive studies on the leaf growth and development of white clover swards. This involved the marking, measurement of development, and classification of individual clover leaves from the bud stage to when they died. The first experiment (Brougham 1958b) measured leaf development of a pure white clover stand for two months from when it was cut to 1 to $2 \mathrm{~cm}$ in mid spring. The leaf area index reached a ceiling of 5.520 days from cutting and remained at about this level thereafter. Of this leaf 3-3.5 units were open, actively photo-synthesising leaves, 0.5 units were buds, 0.5 units were small axillary leaves, and 1-1.5 units were senescent. Resulting from the changing light environment of the developing clover canopy, laminaeof leaves initiated after ceiling leaf area index was attained were twice the size of first formed leaves, and petiole dimensions were 2.5 and 4 times the length and weight respectively. The observations on clover leaf death that reached a significant level 20 to 30 days after defoliation were related to the turnover of symbiotically fixed nitrogen. However, more emphasis was placed on reducing the loss of herbage dry matter by avoiding long spelling of clover dominant pasture.

These observations were extended to follow the changes in undefoliated stands of white clover during a complete year
(Brougham 1962). The amount of leaf present in the stands and clover leaf dimensions (Figure 11) changed markedly with season being at a minimum in winter and highest in late spring. These changes were determined by an equilibrium between the light environment and leaf growth that ensured a high percentage of incident light was intercepted by actively photosynthesizing leaves, Maintenance of this equilibrium involved changes in the rates of initiation and senescence of leaves, the number of leaves per unit area, and leaf dimensions. The discussion about these changes endeavoured to separate the various controlling environmental factors. Variation in temperature levels and moisture supply set the limits within which changes in the intensity, duration and quality of light were effective. The study emphasised the largescale alterationsof processes involved in leaf development brought about by defoliation of the clover leaf canopy, followed by a rapid readjustment of the leaf canopy to a state of equilibrium with incident light levels.

The third experiment in this series observed the effects of red clover on the leaf growth of white clover under long spelling in summer (Brougham, 1965a). Red clover resulted in marked reduction of the weight and number of white clover leaves and buds and increased leaf etiolation. The practical recommendation arising from this study was that where red clover was included in a pasture mixture for its ability to produce herbage in drier summers, management should ensure that it should not

Figure 11 Changes of the dimensions of a time series of marked leaves in an undefoliated stand of white clover in the course of a year (Brougham 1962). The vertical bars are two standard errors in length.

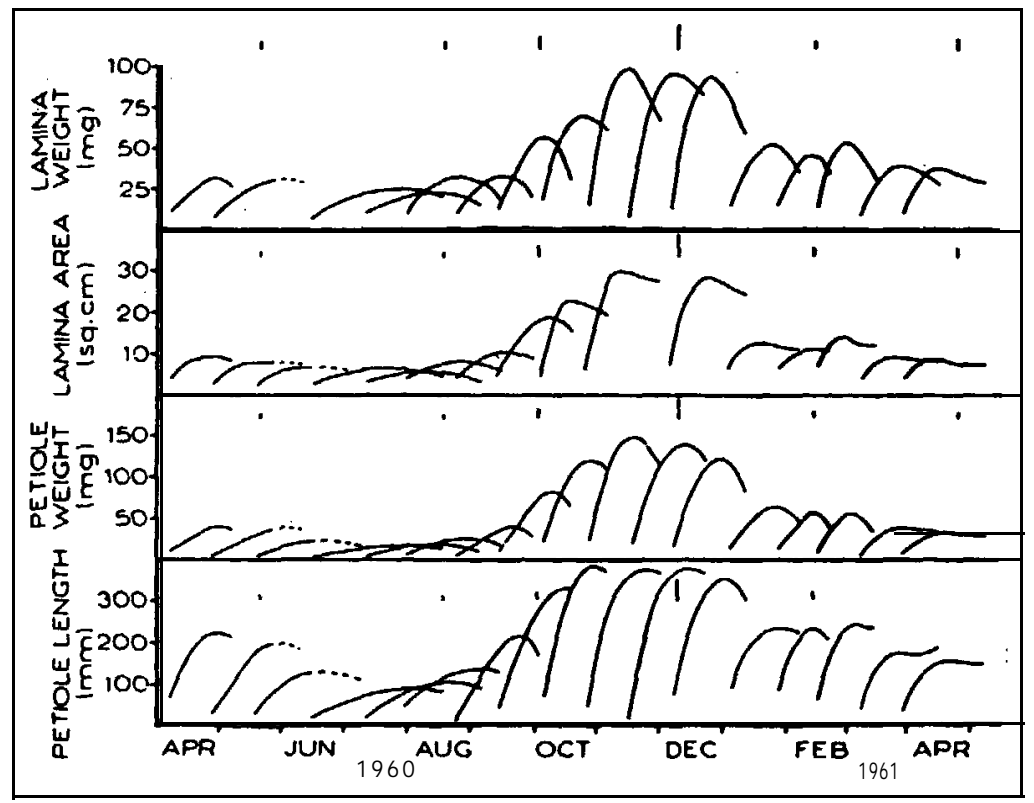


dominate white clover to the extent that the nitrogen fixing capacity of the pasture was impaired.

In connection with his detailed clover studies Ray Brougham's first major overseas involvement appears to be his attendance at the $\mathrm{X}$ International Botanical Congress in Edinburgh in 1964 for which he prepared a paper on factors affecting grass-legume balance in grazed pastures (Brougham 1964). He did not deliver the paper because the previous speakers in the session in which he was involved took up the time allotted for his presentation. This experience may have influenced his strong motivation to encourage broad and active participation by those attending grassland conferences. His ambitions in this respect were apparent in the organisation and outcomes of the XVII International Grassland Congress at Palmerston North in 1993.

\section{Administrative responsibilities, recruits and co-workers}

In 1960 Ray Brougham became head of the Pasture Ecology Group of Grasslands Division when Dr B.R. Watkin took up a position at the University of New England, Armidale, Australia. Later Bram Watkin was to return to Massey University as Professor of Agronomy, and their long association was very important in the strong links that developed between the Agronomy Department and Grasslands Division.

This appointment to an administrative position was at a time when-DSIR-was-expanding-its_activities_and actively recruiting and supporting university science students in their ongoing studies, many to doctoral degrees. My involvement with Grasslands Division and grassland research began at this time. By then Ray Brougham was confident in his ability as a research worker, had an international reputation in grassland science and had developed a network of contacts with grassland farmers and farm advisors. He readily interacted socially with the young science recruits and involved them in the discussion and testing through experimentation of his evolving ideas. Amongst these people-he-found coauthors, and for a greater number he had an important influence on the lines of research they followed.

\section{Characteristics of the base of pasture, senescence and decomposition}

Brougham's studies of the production and senescence of tissue in undefoliated white clover stands were extended to obtain similar information for Italian ryegrass (Lolium multiflorum) in a collaborative study with Tony Hunt (Hunt \& Brougham 1966). Tiller numbers declined progressively and the rate of leaf appearance and mature leaf size increased in a undefoliated stand of Italian ryegrass over a period of six months from winter to summer. The average number of mature leaves per tiller remained relatively constant during the winter months but increased in spring. Total yield, particularly stem tissue, increased progressively from early spring. This study emphasised the loss of dry matter in undefoliated stands of ryegrass. It was the precursor to a study of structural changes of stubble developed under the frequent-lax grazing that Brougham recommended for ryegrass-based pastures in summer (Hunt \& Brougham 1967). This study followed the growth in late summer of a perennial ryegrass sward cut at seven day intervals to a height that left sufficient herbage to intercept 90 to $95 \%$ of incident light at noon. After initial increases following the first cuttings, tiller numbers and the amount of green leaf tissue declined over the 49 days of the study. Yields of sheath and dead matter increased progressively during the same period resulting in a sward of relatively low photosynthetic capacity. This emphasised the need for hard "clean up" grazing in autumn following the recommended frequent but lax grazing of pasture during summer. Warren Hunt followed these studies by focusing on leaf death and decomposition in pasture, and acknowledged the guidance and encouragement Ray Brougham provided in support of his work (Hunt 1970, 1971).

\section{Ryegrass persistency and genotypic changes}

-Using the short-rotation-based pastures-from-his-study - ...... of the effects of frequency and intensity of grazing (Brougham, 1959b), Brougham collaborated with Glenday and Grasslands Division plant breeder Steve Fejer in determining the genetic structure of the resulting ryegrass populations. As a hybrid, short-rotation ryegrass had a wide genotypic structure with the potential to be changed by selection induced by different grazing systems (Brougham et al. 1960). They found that there had been selection towards perennial ryegrass types_under frequent-hard grazing and towards Italian ryegrass types with infrequent-lax grazing. This study showed the usefulness of the simply inherited characters of root fluorescence under ultra-violet light and seed awning as markers in genecological studies of ryegrass (Figure 12).

The technique was applied to a mixture of "Grasslands Ruanui" ryegrass and "Grasslands Manawa" short-rotation ryegrass to start from an even wider genetic base than that provided by "Manawa" alone (Brougham \& Harris 1967). Within six months from sowing lax grazing brought about a marked shift towards plants with "Manawa"-like characteristics and "continuous-close grazing caused a shift to "Ruanui" like plants (Figure 12). After this initial 
rapid change further shifts in the genotypic structure of the ryegrass populations were more gradual until the observations were concluded three years from sowing. More detailed study of the genotypes of the surviving populations were made in the sixth year from sowing (Harris \& Brougham 1970). By then $96 \%$ of the ryegrass forming the lax-grazed pasture were "Manawa-like" indicating that this cultivar was persistent under this management. By contrast only $12 \%$ of the ryegrass remaining with continuous grazing were "Manawa-like", and these genotypes had vegetative characteristics intermediate between those of "Ruanui" and "Manawa". These results were discussed in respect to the formulation of seeds mixtures suitable for different grazing management systems, and the indicated potential for selection of genotypes with elements of L. multiflorum characteristics able to persist under frequent-hard grazing. We extended this line of study to following changes in the genotypic structure of ryegrass populations sown on hill, terrace and sand dune country in the Manawatu. Results from the hill pasture are presented in Harris (1973).

Related to these studies of changes in the genotypic structure of ryegrass populations was a specific study of factors influencing the persistency of short-rotation ryegrass (Brougham 1961 b). In particular this emphasised the higher elevation of thegrowing points of short-rotation ryegrass compared to those of perennial ryegrass, especially during the flowering period. Consequently short-rotation ryegrass was more susceptible to hard grazing during this period, and this contributed to its poor persistency under hard summer grazing (Figure 13).

\section{Botanical composition and browntop}

From when his experimental work started, beginning with the pasture establishment studies, Brougham made observations on the changes of botanical composition

Figure 12 Changes in the characteristics of surviving ryegrass plants in a mixed sowing of 'Grasslands Ruanui' and 'Grasslands Manawa' ryegrasses under three grazing treatments (Brougham \& Harris 1967).
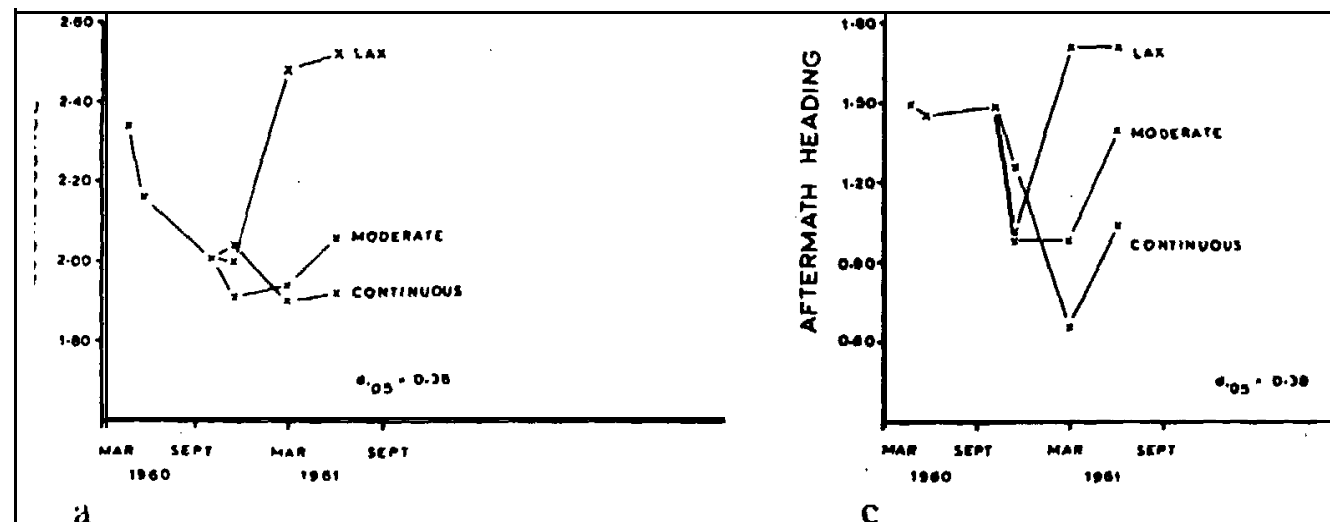

d
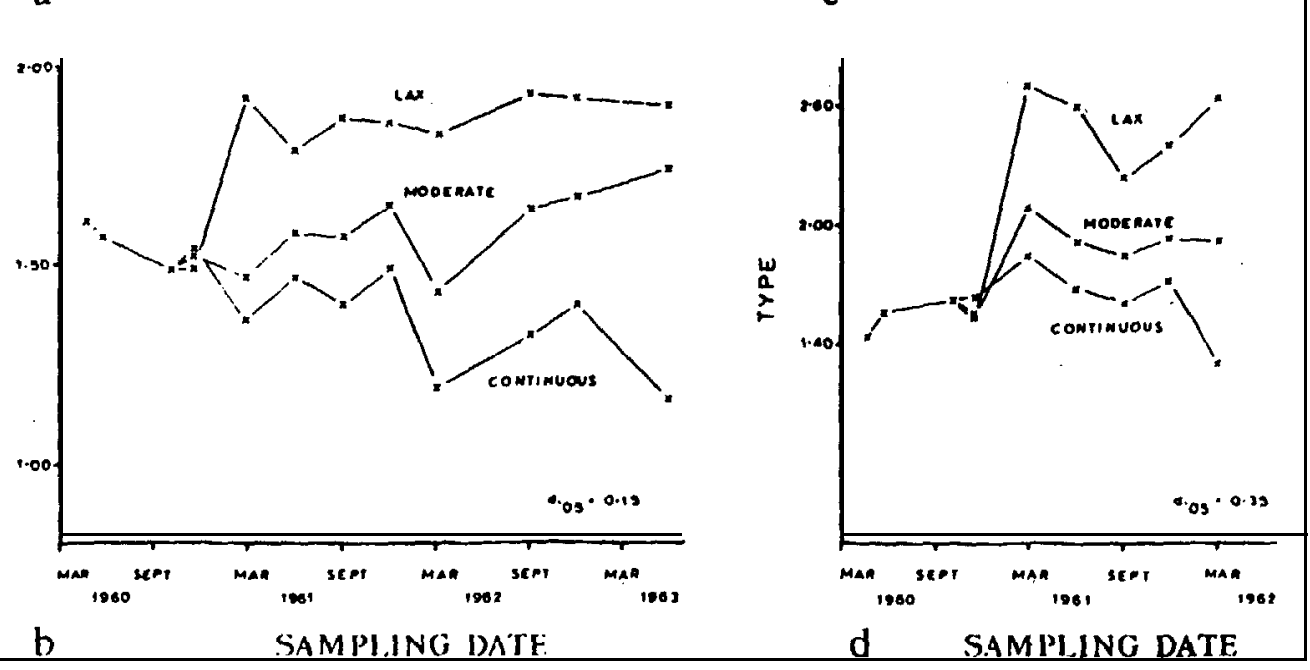
Figure 13 Percentages of 'Grasslands Ruanui' and 'Grasslands Manawa' growing points above 1 in. $(2.5 \mathrm{~cm})$ and 2 in. $(5 \mathrm{~cm})$ in laxly and close and continuously grazed pasture (Brougham 1961b).

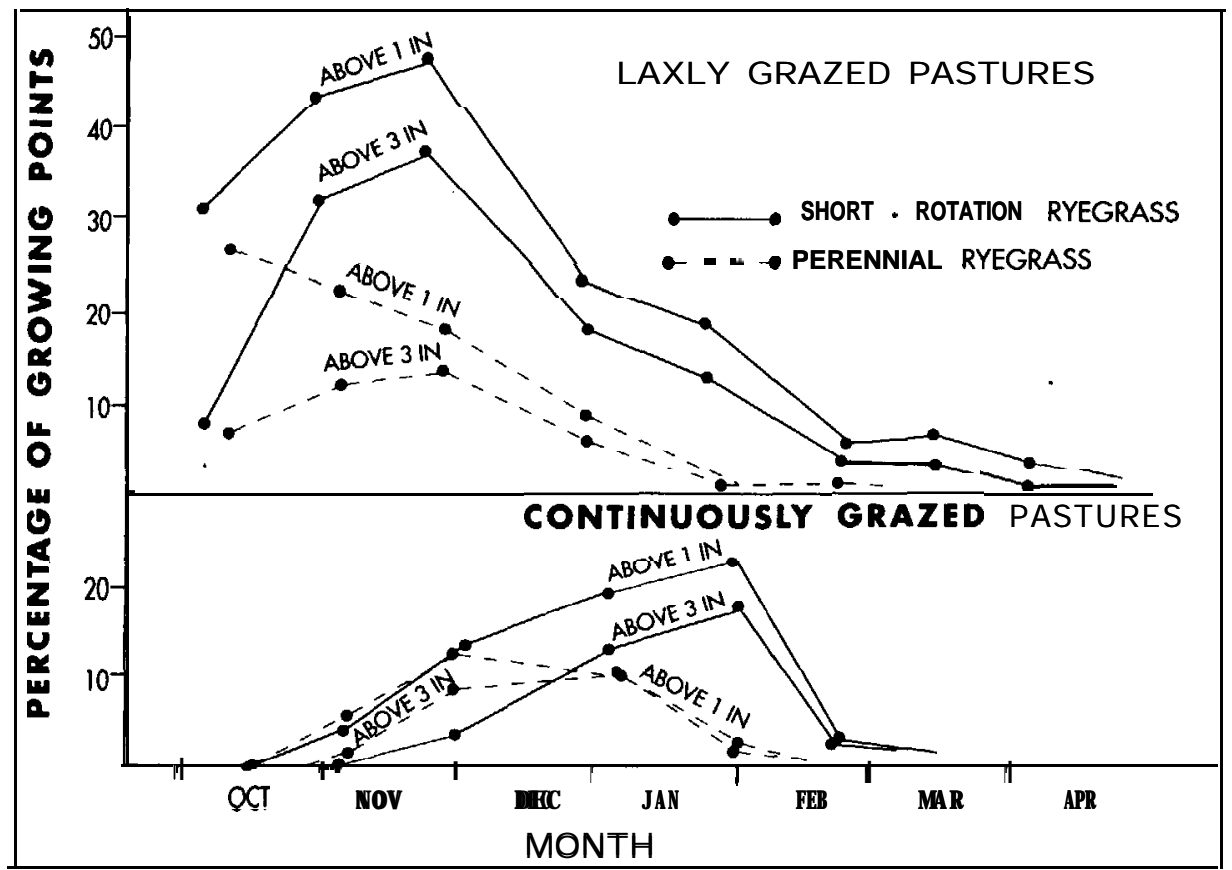

caused by the cutting and grazing treatments applied. This work was with young pastures in which the sown grasses and legumes remained as the dominant species

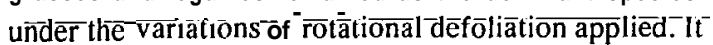
was not until the studies of changes of genotypic structure of ryegrass populations that a continuously grazed treatment was studied. The structure of the botanical composition of this treatment compared to rotationally grazed pasture was the subject of a study (Harris \& Brougham 1968) that linked in to wider consideration of pasture composition and management systems beyond the fertile lowland soils of the Manawatu. Continuousclose grazing had brought about the marked ingress of browntop (Agrostis capillaris), Poa species and a number of prostrate dicotyledonous weeds, whereas the rotationally grazed swards remained ryegrass-clover dominant. In the continuously grazed treatment browntop showed a negative association with ryegrass, while ryegrass, POa and white clover were positively associated. These species associations were characteristic of the wet hill country of the North Island where after the sowing of ryegrass based seeds mixtures pastures usually developed rapidly towards browntop dominance (Harris 1973). The differences of botanical composition between rotationally and continuously grazed pasture provided the stimulus for my experimental studies of the competitive interactions between ryegrasses, browntop and white clover (Harris \& Thomas 1970).

The frequency of occurrence of browntop in different topographical and soil type areas of the Manawatu was investigated-in surveys undertaken in 1967 and 1968 (Brougham et al. 1974). It was found that the frequency of occurrence of browntop in hill country was more than $80 \%$, less than $40 \%$ on terrace country and less than $20 \%$ on flat country. Browntop content was generally less in dairy than in sheep pastures, and differences of browntop content on hill country farms were noted according to the management systems used. This study was influential in the focus on evaluating rotational grazing systems in the research programme undertaken on the Ballantrae moist hill country regional station in the Manawatu acquired by Grasslands Division in 1966 to replace the hill country site at Te Awa.

\section{Animal factors}

Although Ray Brougham was primarily a plant scientist and particularly a plant ecologist, the animal factor was always part of the research he undertook, and consideration of this factor became stronger as his work progressed. One of his earliest duties at Grasslands Division was the unpleasant task of collecting and returning urine and dung from sheep in Sears' (1953a, b, c) pasture growth and soil fertility experiments. 
Certainly this experience would have contributed to his concern and knowledge about the roles of grazing animals and legumes in nitrogen cycling, and he supported further study of these roles while he was Director of Grasslands Division.

In the period up to the mid-1960s there were practical limitations to the scope of grazing studies that could be undertaken by Grasslands Division, particularly on the limited area of lowland fertile soil at Palmerston North. There was a tacit agreement that DSIR should focus its effort on more fundamental and particularly plant related grassland research, leaving the animal and more applied aspects to researchers in the Department of Agriculture. Even so, this tacit agreement did not deter Dr C.P. McMeekan, Head of the Department of Agriculture Research Station at Ruakura, Hamilton, from making scathing comment about the scale and practical relevance to grassland animal production of research undertaken by Grasslands Division.

Brougham's early grazing experiments were conducted on small areas and used sheep as the grazing animal on an on-off basis, measuring treatment responses by herbage production and not by animal production. However he did work in collaboration with animal scientists at Massey Agricultural College and with DSIR Plant Chemistry Division scientists involved with detailed aspects of animal physiology. Through these involvements he was well aware of relationships between pasture quantity and quality and livestock production and health (Flux et al. 1960; Rae et al. 1963, 1964). Others in Grasslands Division picked up and developed further Brougham's collaborative involvements in relationships between pasture quality and animal performance and health (Lancashire \& Keogh 1966a, b). However when Grasslands Division purchased 125 ha at Aorangi on the Kairanga Plains, Manawatu in 1967, he grasped the opportunity to test his ideas by experiments measuring herbage and livestock production and investigating interactions between plant and animal in larger-scale, self-contained grazing systems. Aorangi became the focus of Brougham's last major phase of experimental work. He remained directly involved in the management and measurement of a series of pasture and livestock production experiments at the site right through his period as Director of Grasslands Division from 1971 to after he retired in 1985 .

In respect to the opportunity provided by Aorangi, the concluding remarks made by Ray Brougham in the plenary paper he presented at the XI International Grasslands Congress at Surfers Paradise, Australia (Brougham 1970b) is interesting. He called for the direction of more effort to the investigation of the many interacting factors in the soil-plant-animal complex of grassland farming with emphasis on ecological studies where the whole rather than part of the complex is studied. While acknowledging the place of computer simulation studies he expressed the-opinion that these should not be undertaken at the expense of studies of the whole. He stated his view that much better use would be made of research data if research workers translated basic results into practise by sensibly-devised and practically-orientated experimentation. This was the nature of the research at Aorangi.

\section{Aorangi and dairy beef}

Unfortunately, a significant part of the results from the Aorangi farmlet studies have not been fully analysed or formally published in scientific journals. However the studies served a valuable role for almost two decades as direct and practical demonstrations to grassland farmers, farm advisors, and the international community of grassland scientists, of the principles of grazing management practice derived by Ray Brougham. He drew on results from these experiments in his frequent role as a speaker at grassland science and farmers meetings, and together with papers published with and by co-workers involved at Aorangi, and in information presented in the Grassland Division Research Reports from 1978 to 1984, the main findings of these experiments are available.

Measurements for the first of the farmlet studies began in 1969 and involved six small farmlets of 1.62 ha stocked with dairy bulls that were predominantly Friesian. This layout allowed three replicates comparing two farming systems (Brougham et al. 1975). The pasture was 20 years old and predominantly perennial ryegrass and white clover with a significant browntop component. The systems compared were self-contained all-year-round rotational grazing with and without a feeding or loafing platform. For the farmlets with platforms, bulls were held on these during wet periods in winter and spring to reduce treading damage and feed wastage by trampling. Hay was conserved in each farmlet and fed back in the farmlet in which it was conserved.

It is interesting that Brougham chose loafing platforms as the treatment comparison as treading damage was the particular specialist interest of his contemporary at Grasslands Division, Don Edmond (Brown \& Evans 1973), who died at an early age in 1971. Edmond had demonstrated significant reduction of herbage yield and changes of botanical composition by treading in small plot experiments, and there was a period in the 1960s when loafing pads were constructed on many New Zealand dairy farms. It is also appropriate to record the involvement of Don Johnston, Consulting Officer, New Zealand Dairy Board, with this farmlet study. I particularly recall the frequent consultation between Ray Brougham and Don 
Johnston driven by their strong motivation to improve the productivity and profitability of grassland farming. Defining potential levels of maximum grassland production, and considering the management options to reach these levels, were probably the strongest element in Brougham's public speaking appearances in the late 1960s and throughout the 1970s. The Aorangi experiment became a focus of Brougham's and Johnston's joint effort to practically demonstrate maximum animal production levels from pasture.

The effect of using a platform was small and it was concluded that feeding or loafing platforms were of limited value (Brougham et al. 1975). It was also shown that there was little or no value in the conservation and feeding out of hay. The better option was to conserve herbage grown during peak periods of growth "in situ" to be held in reserve to feed to the bulls in periods of low pasture growth. The most significant outcome of this farmlet experiment was that it demonstrated that high yields of dairy beef could be obtained by the system of grazing management used. The statement of animal production "greater than $1000 \mathrm{~kg}$ hot-carcass weight per hectare" became a common phrase in Brougham's presentation of his results from the Aorangi farmlet studies. This carcase yield level was indicated to be five times higher than the average yields produced from intensive North Island fattening units at the time of the study.

Brougham considered that the basis of this high level of animal production was thesystem of rotational grazing used. Consequently, description of the rotational grazing management system is of more iñterest than the platform comparison. In mid-spring (November) three month old weaner bull calves were bought on to the farmlets and were maintained on these at a stocking rate of 7.4 bulls/ ha to 16 to 20 months of age when they were killed. Feed shortages, usually caused by the onset of summer dry weather, determined killing time. Consequently, for a period of 1-4 months in late spring and summer there was overlap of older bulls and weaner calves. During this overlap period the calves were grazed as leaders and the bulls as followers.

The key pasture management process was the implementation of daily rationing of herbage available to the bulls with the onset of autumn rains. This was achieved by block rotational grazing involving stock control with portable electric fences, and allowed the farmlets to get in to long rotations. This had the joint effect of increasing pasture growth in response to autumn rain and carrying herbage forward into winter and early spring during which times current herbage growth was less than that required to maintain the growth of the bulls. Over the four years of the experiment reported, the first autumn rotation, which began around 1 April, provided a spell between grazing of 62 to 73 days, the second from 46 to 54 days, and the third which carried the farmlets into the period of maximum spring growth, 31 to 43 days. Thereafter through spring and summer the rotation varied around 32 days. As a consequence the paddocks in each farmlet were grazed 10 to 11 times each year. In respect to his earlier grazing experiments it is relevant to note that the implementation of block grazing in autumn, implemented most directly for feed rationing and "in situ" herbage conservation, also served as an "autumn clean up grazing" to condition the pasture for winter and spring growth (Brougham 1960). However the need for a long rotation over winter to carry feed forward compromised the potential benefit of reducing herbage loss by decomposition by more frequent defoliations during this season (Brougham 1956a).

The important effects of the intensity of summer grazing identified in Brougham's earlier studies (Brougham 1960a, 1961b) were the focus of a farmlet study that began in 1973 and continued to 1977. The treatment contrast was between overgrazing for a month in summer compared to management to avoid overgrazing. The brief reporting on the animal production outcome of this experiment was that there were appreciable differences in bull performance in autumn and early winter after summer overgrazing, but for the full year the treatment effect was small (Grassland Division 1978a). This study was used to compare techniques for measurement of the feed intake of the bulls (Clark \& Brougham 1979) and the patterns of compensatory growth of the bulls that evened out their liveweights on the treatments are shown. The suggestion arising from this study that animal production from the system could be obtained by improving pasture digestibility in summer by inclusion of improved summer-active pasture varieties was investigated in the next farmlet study.

Attainment of dairy beef production in the first farmlet study many times greater than that prevalent in current farming practice on old pasture with a high content of browntop posed the question as to whether inclusion of herbage cultivars selected by Grassland Division could increase productivity further. Comparatively few- experiments have endeavoured to measure the improvements of animal production by the use of selected cultivars, and the responses in many of these experiments have been small or inconclusive. As breeding and selection of pasture cultivars was a major function of Grasslands Division, Brougham as Director of the Division saw the need to demonstrate the contributions new cultivars could make to animal production under appropriate management. In 1977 two farmlets with the "old" permanent pasture were compared with four farmlets sown with a "new" pasture which was a mixture of 'Grasslands Nui' perennial ryegrass, G.4708 hybrid ryegrass, 'Grasslands Pawera' tetraploid red clover, and 'Grasslands Pitau' white clover. 
These were the new generation of Grassland cultivars that had become available since the standard ryegrassclover mixture used to establish the pastures that Brougham had experimented with 20 years previously. The stocking rate of dairy bulls and thesystem of rotational grazing management was similar to that of the previous farmlet studies.

Results from this experiment were briefly presented at several conferences, most notably in Brougham's keynote address to the XIV International Grasslands Congress at Lexington, Kentucky, U.S.A. in 1981 (Brougham 1983).

Table 1 Net hot carcass meat yields ( $\mathrm{kg} / \mathrm{ha})$ from "old" and "new" pasture.

\begin{tabular}{lccc}
\hline Year & Old pasture & New pasture & Difference(\%) \\
\hline $1977 / 78$ & 908 & 1052 & $146(16)$ \\
$1978 / 79$ & a44 & 938 & $94(11)$ \\
\hline
\end{tabular}

In reviewing this result I consider it appropriate to point to some of the issues it raises. Most obvious is the need to assess whether the gain of meat production offset the cost of establishing the new pasture. There remains the untested question of whether use of the first generation of Grasslands cultivars that Brougham used in his pasture establishment studies would have given a different result to that obtained by using the new generation of cultivars. And there is the concern that the meat yields from the "old" pasture were less than those of the first experiment which were about the same as those from the "new" pasture.

Arising out of this farmlet experiment and the role of pasture quality in summer raised in the paper by Clark \& Brougham (1979), came a particular focus on red clover as it was considered to be the main contributor to the gain shown by the "new" pasture (Brougham \& Cosgrove 1985; Cosgrove \& Brougham 1988). A separate trial was established that compared the effects on the herbage production and botanical composition of the "new" cultivar pasture of year round infrequent grazing with treatments that were grazed frequently in either winter or summer (Cosgrove \& Brougham 1985). These treatments all produced about $15 \mathrm{t} \mathrm{DM} / \mathrm{ha}$ but it was found that frequent grazing in summer and also in winter decreased red clover yield. Particularly with frequent grazing in summer, there was a marked increase of ryegrass yield in spring and summer to compensate the reduced red clover yield. This result suggested the use of strategic summer grazing to control the red clover-ryegrass balance.

It is pertinent in two respects to comment on grazing experiments focusing on red clover that I was involved in at Aorangi when the farmlet studies were under way
(Harris et al. 1980; Harris \& Kunelius 1988; Kunelius et al. 1982; Pineiro \& Harris 1978a, 1978b). The first comment is that while the farmlet studies were founded on Brougham's direct experience of experimentation and contact with grassland farmers and advisors, he was continually looking at contemporary experiments and incorporating findings from these in the management variables tested on the farmlets. The second is to point out the important involvement of overseas scientists in Grasslands Division work many of whom were attracted to New Zealand by Brougham's overseas contacts and international reputation. The findings of evaluation of red clover cultivars and grass mixtures in collaboration with Juan Piniero from Spain, and direct drilling studies with red clover in collaboration with Tapani Kunelius from Canada, were applied in the "new" pasture farmlet evaluation.

Commencing in 1979 a farmlet experiment on the "old" pasture compared treatments with no fertiliser nitrogen, $100 \mathrm{~kg}$ nitrogen ha/yr applied as urea in late autumn and early spring, and the same rate applied in early spring and early summer. The latter treatment gave the best response by increasing meat production by 7 to $8 \%$ annually and reduced clover content only to a small extent (Grasslands Division 1982a). In 1981 this experiment was modified by replacing the spring nitrogen application treatment with a nitrogen plus spray irrigation treatment. Irrigation was applied to prevent the soil moisture deficit from exceeding $50 \mathrm{~mm}$, and about 250 $\mathrm{mm}$ was applied in the period November to March (Grasslands Division 1984). Irrigation enabled the bulls to be carried for a longer period into summer and early autumn resulting in higher carcase weights (Table 2).

Table 2 Pasture and dairy bull production responses to irrigation (Brougham \& Cosgrove 1985).

\begin{tabular}{llrr}
\hline Pasture & Herbage kg DM/ha & Dryland & Irrigated \\
\hline & Annual & 16970 & 18030 \\
& Summer & 5510 & 6040 \\
& Autumn & 2840 & 3500 \\
\hline Dairy bull & Liveweight gain (kg/ha/yr) & 2160 & 2340 \\
& Mid-summer liveweight & & \\
& gain (kg/head/day) & 0.73 & 1.02 \\
\hline
\end{tabular}

Following on from the "new" pastures study, in 1981 the "new" pastures were replaced with a mixture of 'Grasslands Nui' perennial ryegrass, 'Grasslands Pitau' white clover, and 'Grasslands Pawera' red clover. This provided duplicated farmlets for three treatments: "old" pasture, "new" pasture and "new" pasture irrigated to offset summer water deficits. In 1985 a further "new" pasture combination which added 'Grasslands Matua' 
prairie grass (Bromus catharticus) to the three species mixture sown in 1981 was included as a comparison. This four-species "new pasture" was grown with or without additional irrigation and fertiliser nitrogen. A summary of the herbage yields and bull liveweight gains (Table 3) from these farmlets for the period 1982 to 1897 was presented at the New Zealand Grasslands Association Conference in 1988 (Cosgrove \& Brougham 1988).

Table 3 Annual dairy bull liveweight gains in three series of farmlet studies (Cosgrove \& Brougham 1988).

\begin{tabular}{llc}
\hline Pasture type & Treatment & $\begin{array}{c}\text { Liveweight gain } \\
\text { kg/ha/yr }\end{array}$ \\
\hline "Old" ryegrass and & "Old" Control & 2187 \\
white clover & + Irrigation & 2361 \\
"New 3-species" ryegrass, & "Old" Control & 1948 \\
white and red clover & "New 3-species" & 2138 \\
& "New d-species" + & 2203 \\
"New-4 species" ryegrass, & "Old" Control & 1829 \\
prairie grass, white and red & "New 4-species" & 1771 \\
clover & "New 4-species" + & 1898 \\
& Irigation + N & 180 \\
\hline
\end{tabular}

The most significant indications of this series of farmlet studies were the consistent increases of liveweight owing to irrigation, and to the "New 3-species" pasture and a negative response from the inclusion of prairie grass. The prairie grass had a particular effect of reducing spring and summer liveweight gains and irrigation was needed to offset this.

Purists in experimental design can find much to be critical of in the Aorangi farmlet studies. Ray Brougham referred to the procedure as "seat of the pants experimentation" and gave a justification of the approach used in his plenary paper at the XIV International Grassland Congress (Brougham 1983). To quote, "Importantly, management procedures are not fixed from year to year, although in any year the same management procedures are applied to the different treatments being compared. The management meets the needs of, and changes in, climatic, animal,-pasture, -and-economic considerations. Using this approach, the aim is to maximise animal production/ha, and to assess differences owing to treatment". He continued to say that "Investigations such as these can be the entering-point for widespread dissemination of research result". There were regular meetings of a discussion group of farmers at the Aorangi farmlets. The farmers evaluated the- results they saw in respect to their experience on their farms. In applying what they saw as practical they made significant contributions to the economics of dairy-beef farming in the Manawatu. I believe a comprehensive collation, analysis and interpretation of the data collected during the course of the Aorangi dairy-bull farmlet would be well worthwhile.

\section{Directorship and widening horizons}

The period during which Dr Lionel Corkill was Director saw a significant advance of the skills of the Grassland Division staff and the facilities available to them for experimental work. Brougham had grasped the opportunity this progress provided by the implementation of his Aorangi farmlet studies. When the resources of Grassland Division came under his control when he was appointed Director in 1971 he had a platform to implement nationwide his vision of realising increases of animal production from New Zealand's pastures.

While he naturally related to people on a one-to one basis, often seeking their individual confidence, a significant means by which Brougham influenced the course of the entire Grasslands Divisions' research programme was through the establishment of a series of research committees. Definition of these committees was proceeded by a requirement for all staff to state the objectives, approach, and progress of all the research projects they were engaged in. While such definition of projects is a routine part of the accountability procedures applied to scientific research in New Zealand today, in 1971 for Grasslands Division scientists this was a novel requirement. Projects were then categorized according to their relevance to farming system or specialist discipline and-listed-in-a-publication-for internal-use-in-Grasslands Division. To a large extent the categorization of the projects related to the research committees that were established. While thecommittees predominantly involved Grasslands Division staff, personnel from other agencies, particularly the Department of Agriculture that later became the Ministry of Agriculture and Fisheries, were also included.

The first of these committees related to the wet hill country of the North Island and was set up in 1971 within a few months of Brougham becoming Director. This committee played a particular role in designing the 100 ha grazing trial at the hill country research station at Ballantrae. The experiment was established as 10 selfcontained farmlets that compared two levels of fertiliser input and three grazing systems (Lambert et al. 1983). The grazing systems, rotational grazing with cattle or sheep and continuous grazing with sheep, were an extension of Brougham's principles of pasture management in to the class of country represented at Ballantrac.

By 197410 research committees were functioning each of which had a specified coordinator. However, Brougham was a member of every one of these 
committees, many of their meetings were held in his office, and heeffectively chaired most of their proceedings while simultaneously conducting other Divisional business. His "open door policy" of management was at time very frustrating for those gathered for a research committee meeting when proceedings were halted while he engaged in lengthy conversations with outside callers!

To report on the outcomes of the different research committees would almost make a history of Grasslands Division during Brougham's period as Director and much of what happened until both DSIR and Grasslands Division were disestablished in 1992. I will limit my attention to two of the committees operating in 1974, the nitrogen cycle and ecotype collection committees.

Providing a link back to Brougham's introduction to grassland research when he was involved with Sears' pasture and soil fertility studies, the nitrogen cycle committee provided the forum for the planning and implementation of studies of nitrogen fixation in pasture at nine representative sites in New Zealand. Sears' study had indicated that clovers fixed up to $650 \mathrm{~kg} \mathrm{~N} / \mathrm{ha}$, and it was widely considered that high $\mathrm{N}$ fixation levels were characteristic of New Zealand pastures. The outcome of this coordinated series of studies was a series of 11 papers published together in the New Zealandjournal of experimental agriculture in 1979. Brougham was coauthor of two of these papers, the introduction (Ballet al. 1979) and the report on the study carried out on the dairy-bull farmlets at Aorangi (Clark et al. 1979). At Aorangi total annual $\mathrm{N}$ fixation levels averaged $225 \mathrm{~kg} /$ ha for the two years of the study, and like the other sites on developed lowland pasture, this was less than half that indicated by Sears. On the unimproved hill country at the Ballantrae hill country research station the average annual $\mathrm{N}$ fixation rate was only $34 \mathrm{~kg} / \mathrm{ha}$ (Grant \& Lambert 1979).

The ecotype collection committee grew out of Brougham's experience of the process of natural selection that occurred in his studies of genotypic shifts in ryegrass populations. The early period of breeding and selection by Grasslands Division was based on the concept of the selected cultivars having genetic bases that were sufficiently wide to allow adaptation to the range of pastoral situations in New Zealand. Brougham saw the potential of more specifically adapted cultivars particularly for areas that were more difficult for pasture production. By 1973 collection of local populations of ryegrass, white clover and browntop from a wide range of sites in wet North Island hill country sites was under way (Forde \& Suckling 1980; Suckling \& Forde 1978). Latercollections were made of dry hill country white clover populations (Grassland Division 1984).

Representatives of products from these collections that are amongst the current generation of herbage cultivars available in New Zealand are 'Grasslands Tahora', a small ieaved densely stoloned white clover adapted to perform on moist hill country pastures, 'Prop', a small to medium-leaved and densely stoloned white clover that seeds prolifically and is adapted to summer dry environments, and 'Grasslands Muster' browntop. Currently more than 50 cultivars selected and bred by Grasslands Division are available compared to the eight that were available when Brougham began his experimental work in the 1950s. Most of the developmental work that led to this large increase of cultivars was done while Brougham was Director. In addition to the three mentioned, many of the other recently released 'Grassland' cultivars have characters that are tailored for performance in specific regions in New Zealand.

\section{Accounting for regional differences of pasture production}

A recurring theme in Brougham's conference presentations in the 1970s, most comprehensively presented in a paper to the Ruakura Farmers' Conference (Brougham 1973a), was the need to address regional differences in pasture production and livestock farming systems in New Zealand. This need was later directed to the international scene particularly when retirement from Grasslands Division freed him from the demands of administration. He worked to strengthen the facilities and staffing at Grasslands Division's regional network of stations linking the programmes of work at the separate stations to meet national objectives. His final Director's report in the Grasslands Division Research Report series (Brougham 1984b) focused on the regional theme. The stations are recorded in this report as Kaikohe (warm temperate), Palmerston North (centre for Grassland Division), Aorangi (nucleus seed production, intensive lowland farming), Ballantrae (moist hill country), Lincoln (dryland farming, seed production), Tekapo (South Island High Country - short growing season) and Gore (cool-temperate - intensive sheep farming).

At the various regional stations Brougham contrived to bring together compatible teams to address particular research topics. For example at Lincoln the effort was focused on lowland and hill country facets of dryland farming, on intensification of forage seed production with separate emphasis on the production of grass and legume seed, and a clear identity was established for grassland research in the South Island high country. In 1982 Grasslands Division established a field station at Lake Tekapo concentrating effort on a 80 ha area whereas previously it had been spread over many site and supported with spartan facilities. 


\section{Transferring information from scientists to grassland farmers}

Ray Brougham's personal determination to present his research findings in ways that were of practical use to farmers and in terms that they understood was extended to the staff of Grasslands Division. He insisted that every scientific article should also have a popular summary written in terms that could be understood by university teachers, students, extension workers and farmers. These summaries were grouped according to region of application or to discipline, and were published for three periods providing a comprehensive record of the Divisions' published work from 1974 to 1982 (Grasslands Division 1978b, 1980b, 1982b).

As well Brougham initiated a series of Research Reports in 1978 (Grasslands Division 1978a, 1980a, 1982a, 1984). In each he gave a Director's report and these provide insight on how he shaped and presented the Division in response to the changing expectations of research organisations arising from economic and political influences. In 1984, the year before he retired as Director of Grasslands Division, a radically different political ideology gained power in New Zealand that acted to demean the principles of public service that Brougham had applied to good effect. It was a good time for him to retire. He was spared the effects of externally imposed accountability processes that diverted effort from research to administration. These changes were stifling to scientific creativity and productivity. Had they been in force earlier they would-have-prevented-him-from-being-actively-involved in research right up to his retirement. Brougham observed with concern the effects of these politically initiated changes on the work and status of Grasslands Division. Fortunately the freedoms of retirement allowed him to continue his interests in grasslands to remarkable effect.

\section{Turf research institute}

Like many fellow New Zealanders, Ray Brougham took a keen-interest in sport-In particular those that he played well and followed throughout his life, rugby football, cricket, golf and horse racing, are sports enhanced by good quality turf.

In 193.2 Sir Bruce Levy had agreed that Grasslands Division should be involved in turf research on behalf of the Greens Research Committee of the New Zealand Golf, Association that had been set up in 1931. The functions of this Committee was taken over by the New Zealand Turf Institute when it was formed in 1939. For 25 years the turf research undertaken for these organisations was located at the Manawatu Golf Club. From 1957 to 1969 the turf research was transferred to the Department of Agriculture and the experimental plots were located at Milson in Palmerston North. This early period of turf research was mainly directed to management to provide a fine, hard-wearing, weed free turf of browntop (Agrostis capillaris) and Chewings' fescue (Festuca rubra).

In 1969 the turf research was taken over by Grassland Division and a turf research section was established. There was a change of emphasis towards the selection and evaluation of turf cultivars and the section was well located to draw on the expertise of several DSIR Divisions who had staff located at Palmerston North. Brougham encouraged the development of the turf research programme and in' the mid-1970s the national office of the New Zealand Turf Culture Institute was established on the Grassland Division site at Palmerston North.

In 1986 Brougham became President of the New Zealand Turf Culture Institute Board of Management and he continued in this role to 1990. Conferment of Life Membership in 1990 was a tribute to his contribution to the Institute during his term as President.

His most visible role in the turf industry was his contribution as Honorary Editor of theNew Zealand Turf Management Journal. He began this role with the first issue of the Journal in July 1986 when it replaced the Sports Turf Review. Brougham wrote the Editorial for ten of the issues of the Journal, the first beginning with "Welcome to New Zealand Turf Management Journal" (Brougham 1986a). The Editorials that followed were written-in ${ }^{-}{ }^{-}$relaxed and ${ }^{-}$interesting style in which he commented on the affairs of the Turf Institute and the Journal, and made comment about personalities in the turf industry, sportsmen, and sport as it is played on turf in different parts of the world. For other issues he used his contacts to add variety to the Journal by arranging guest editorials. The Editorial Page of the November 1993 issue of theNew Zealand Turf Management Journal is devoted to an Obituary, Raymond Wilkie Brougham, D.Sc; MBE; 1926-1993.

In the February 1990 issue Brougham introduced a new column that he titled "Something Different". He wrote eight articles for this column recounting his visits to sportsfields and contacts with turf and sports personalities throughout the world. The final paragraph of his article about "Bowls - Brazilian Style" (Brougham 1990b) that recounts his experience of game in Porto Alegre, shows Ray Brougham's ability to meet and communicate with people throughout the world - "It was a pleasant interlude, made all the more interesting and enjoyable by the friendliness of the participants, a common occurrence in most countries if one bothers to take time out to show interest in others' customs and activities". 


\section{International consultancies}

Ray Brougham's reputation as a grasslands scientist, competence in practical aspects of animal husbandry, and experience in research administration led to considerable involvements in consultancies. For world aid agencies such as the World Bank and FAO he was involved in consultancies in Argentina, Brazil, Cuba, Chile, Colombia, Ethiopia. the Himalayas, North Korea, Spain, and Uruguay. These consultancies were mostly concerned with evaluations of national pasture and animal research programmes and planning for improvements in research capability to meet national problems.

Involvement with a consortium of New Zealand commercial companies took him to China many times and he was also involved in a consultancy relating to New Zealand's scientific collaboration with Mexico. The work in China was principally in Shansi, Dushan and Gansu Provinces where he was engaged in projects concerned with pasture and land development including seed production, sheep farming, beef production. phosphate production and land development.

As well, he had direct requests from organisations in overseas countries to comment on and assess research programmes in pasture and animal production and to make recommendations for staffing, organisational structures, funding and the direction of research. These assignments also involved comment on the interrelationships between research scientists, extension workers and farmers. In this way he became involved with the Texas A \& M University and Penn State University, U.S.A.: A Foras Talúntais, Eire; and the South African Ministry of Agriculture.

On behalf of the New Zealand Government he assessed the methods of evaluation of New Zealand bred cultivars in ten European countries. As well as the countries already listed he made contributions to meetings in Australia, Austria, France. Germany, India, Japan, the Netherlands, Poland, South Korea, and the United Kingdom.

Through these international involvements Ray Brougham met with a large number of the world's leading grassland scientists and became friends with many of them. His network of international contacts was a key part in the realisation of the vision he had for the format of the International Grasslands Congress.

\section{The international grasslands congresses}

The Seventh International Grasslands Congress was held in Palmerston North, New Zealand, in 1956. As a 30 year-old scientist having recently produced his first scientific papers this was Brougham's first major contact with the international community of grassland scientist. By today's standard of international meetings it was a small congress with 285 in attendance of whom 105 were from New Zealand. Brougham's name appears in the Proceedings with references to his early papers on pasture establishment and pasture growth, and he contributed to the discussion on the paper on "Competition Among Pasture Plants" given by Professor C.M. Donald (Donald 1956). Donald's work was very influential in the development of Brougham's understanding of the role of light interception in pasture growth and botanical composition, an understanding that he in turn passed on to me.

Ray Brougham's intense dislike of flying kept him from greater participation in the international grasslands research for many years. However he was invited to present a plenary paper at the XI Congress at Surfers Paradise, Australia (Brougham 1970b), and I particularly recollect his enjoyment of that occasion. I also was with him with the small number of New Zealanders who attended the XIII Congress at Leipzig in 1977. He did not present a paper at this congress and disliked the formalities and restrictions of the venue and arrangements. This was in contrast to his impressions of the alternative international grasslands meeting in 1977 at Dublin, Eire, where he was invited to present a keynote paper (Brougham 1977a). This meeting had a far more participatory format with poster paper sessions and periods of extended discussion. It was immediately after returning from these European meetings that he experienced a serious coronary attack. He made a good recovery from this responding with sensible adjustments to his lifestyle. In no way did this health problem lessen his resolve and efforts to advance the progress of grasslands research and its application.

He often spoke to me, and undoubtably many others, about his concern that the growing size of the International Grasslands Congresses was limiting participatory discussion, that increasingly it was not attractive to extension workers and farmers, and that it was very difficult for grassland research workers from Third World countries to become involved in the proceedings. He was invited to give a plenary paper to the XIV International Congress at Lexington, Kentucky in 1981 titled "Practical livestock-forage systems: model to manager" (Brougham 1983). In this paper he emphasised the need for hard factual data on livestock-forage systems for all regions of the world. He expressed his belief that the research workers who succeeded were those prepared to "get outside, get muck on their boots, and are not too bedeviled by the biometricians and the modellers". In his opinion the best researchers are generalists who associate with extension workers and farmers and if possible work together with them in teams. In the discussion that 
followed he expressed his disappointment that although he had referred to the situation of "emerging countries" no one from these countries had joined in the discussion.

It was at the Lexington Congress that Brougham became significantly active in the business side of the International Grassland Congress. At the final business meeting he proposed a resolution that the Continuing Committee of the Congress should reorganise and set up a number of "Chapters" that would be responsible for "smaller international meetings embracing the different climatic and topographic regions of the world".

At the XV Congress at Kyoto Ray Brougham was elected as the -Region 5, Australia and New Zealand, representative on the International Grassland Congress Continuing Committee, 198.51988. The XVI Congress was scheduled for Nice, France, in 1989, and it was here that it was determined that the XVII Congress would bc held in New Zealand. As President of the Organising Committee for the XVII International Grassland Congress, Brougham worked with dedicated effort for the next four years to ensure that the Congress would be organised to meet the vision he had discussed for many years.

I am certain that those who were closely involved in the organisation of the XVII Congress could write interesting accounts of the trials, tribulations and triumphs of that process. From the sideline I saw and heard a little about the process, but what was clear was Ray Brougham's absolute determination that his ideas for the running of the Congress would be implemented. Recognising the costs involved in encouraging participation of people -from throughout-the-world;-and-especially-those-fromdeveloping countries, his personal effort was in large part responsible for raising NZ\$1.3 million sponsorship to meet the greater part of the NZ\$1.8 million budget of the Congress.

In his Presidential Address to the XVII Congress he set down six key objectives that were used in the formulation of the Congress (Brougham 1993). These were:

1. For New Zealand and Queensland, Australia to share the Congress ${ }^{\mathrm{so}}$ that the venues would cover a wide range of the climates of the world.

2. Giving equal emphasis to seeing grassland agriculture in action as to talking about and listening to others talk about it.

3. Including smaller rural population centres as venues, preferably those with universities involved in grassland agriculture. The venues were at Palmerston North, Hamilton and Lincoln, New Zealand, and Rockhampton in Queensland.

4. Having a presentation format that encouraged participation and structured discussion involving all attending the Congress.
5. Involving delegates from developing countries in prominent roles in the Congress.

6. Ensuring representation from as many countries as possible by assisting to meet costs involved in travelling to New Zealand to attend the Congress.

The Congress met all these objectives with outstanding success. In posing the question "Why we are here ?'in the Presidential address, Ray Brougham stated that perhaps the greatest challenge was to "reestablish all those involved in the custody of the world's grasslands as caring, innovative, and essential people with important and vital contributions to make for the world's good". He provided an excellent model for these attributes.

\section{Conclusion}

Ray Brougham was an exceptionally perceptive research scientist who was quick to identify the essence of grassland related problems, and investigated these by direct and effective means. He gave first priority to addressing practical problems in grassland farming and was exceptionally effective in transferring his findings, philosophy, and experience about grasslands to farmers.

$\mathrm{He}$ was a person with a far reaching and wide vision of the problems and potential of grasslands production both nationally and internationally, and in particular in his later years, did his best to assist the needs of the developing nations.

-He-was-a-man-with-a-vision-for-the-efficient-andsustainable use of the world's grasslands, who by his own example and by the encouragement of others to share this vision, worked with dedication to bring this vision to reality.

\section{ACKN O W LEDGEMENTS}

To Ray Brougham's family for the hospitality, tolerance and understanding they showed to me in the course of my joint work with Ray, and to those of the network of grasšland workers associated $\overline{\text { with }}$ Ray who provided information included in this review.

\section{BIBLIOGRAPHIC REFERENCES}

Papers to which R.W. Brougham contributed as an author are listed in alphabetic order according to the first author and then in chronological order. Not all of these papers are cited in the text. Other papers cited in the text for which R.W. Brougham was not an author are given at the end of this list. 
Ball, P.R.: Brougham, R.W.; Brock, J.L.; Crush, J.R.; Hoglund, J.H.; Carran, R.A. 1979. Nitrogen fixation in pasture. I. Introduction and general methods. New Zealandjournal of experimental agriculture 7: $\quad$ l-5.

Brougham, R.W. 1953. Seeding rates of short-rotation ryegrass. Proceedings of the New Zealand Grassland Association 14: 172-181.

Brougham, R.W. 1954a. Pasture establishment studies. I. The effect of grass seeding rate on the establishment and development of pasture of shortrotation ryegrass, red and white clovers. New Zealand journal of science and technology A35: 518-538.

Brougham, R.W. 1954b, Pasture establishment studies. II. The influence of herbage height at grazing and of grass seeding rate, on the establishment and development of pasture of short-rotation ryegrass, red and white clovers. New Zealand journal of science and technology A35: 539-549.

Brougham, R.W. 1954c. Pasture establishment studies. III. Barley as a cover crop in establishing pastures for the production of late autumn and winter greenfeed. New Zealandjournal ofscience and technology A36: 47-59.

Brougham, R.W. 1954d. Pasture establishment studies. IV. A comparison of mixtures containing shortrotation ryegrass, perennial ryegrass, or both, as the grass component. New Zealand journal of science and technology A36: 365-374.

Brougham, R.W. 1954e. Pasture establishment. Proceedings of the 7th Ann. Mtg Dairyfanners, Massey Agricultural College: 29-34.

Brougham, R.W. 1955. A study in rate of pasturegrowth. Australian journal of agricultural research 6: 804 812

Brougham, R.W. 1956a. The rate of growth of shortrotation ryegrass pastures in the late autumn, winter and early spring. New Zealand journal of science and technology A38: 78-87.

Brougham, R.W. 1956b. Effect of intensity of defoliation on regrowth of pasture. Australian journal of agricultural research 7: 377-387.

Brougham, R.W. 1957a. Pasture growth rate studies in relation to grazing management. Proceedings of the New Zealand Society of Animal Production 17: 4655 .

Brougham, R.W. 1957b. Grazing management in relation to pasture production. Proceedings of the Ruakura Farmers Conference 1957: 149-1 55.

Brougham, R.W. 1957c. Some factors that influence the rate of growth of pasture. Proceedings of the New Zealand Grassland Association 19: 109-116. Brougham, R.W. 1958a. Interception of light by the foliage of pure and mixed stands of pasture plants.
Australian journal of agricultural research 9: 3952.

Brougham, R.W. 1958b. Leaf development in swards of white clover. New Zealandjournal of agricultural research 1: 707-718.

Brougham, R.W.; Glenday, A.C.; Reid, C.S.W. 1958. Bloat in cattle VIII. Prevention by pasture spraying with anti-foaming agents. Preliminary experiments with non-lactating dairy cows and sheep. Appendix. The effects of emulsified peanut oil sprays on the growth of red clover. New Zealand journal of agricultural research 1: 363-364.

Brougham, R.W. 1959a. The effects of season and weather on the growth rate of a ryegrass and clover pasture. New Zealand journal of agricultural research 2: 283-296.

Brougham, R.W. 1959b. The effects of frequency and intensity of grazing on the productivity of a pasture of short-rotation ryegrass and red and white clover. New Zealand journal of agricultural research 2: 1232-1248.

Brougham, R.W. 1959c. Pasture establishment and management. Massey Agricultural College Sheepfarming Annual 1959: 95-103.

Brougham, R.W. 1960a. The effects of frequent hard grazings at different times of the year on the productivity and species yield of a grass-clover pasture. New Zealand journal of agricultural research 3: 125-1 36.

Brougham, R.W. 1960b. Pasture growth and grazing management. Massey Agricultural College Dairyfarming Annual 1960: 51-62.

Brougham, R.W. 1960c. The relationship between critical leaf area, total chlorophyll content, and maximum growth rate of some pasture and crop plants. Ann. Bot., Land. n.s. 24: 463-474.

Brougham, R.W.; Glenday, A.C.; Fejer, S.O. 1960. The effects of frequency and intensity of grazing on the genotypic structure of a ryegrass population. New Zealand journal of agricultural research 3: 442453.

Brougham, R.W. 1961a. Factors limiting pasture production. Proceedings of the New Zealand Animal Production Society 21: 33-46.

Brougham, R.W. 1961b. Some factors affecting the persistency of short-rotation ryegrass. New Zealand journal of agricultural research 4: 516-522.

Brougham, R.W. 1962. The leaf growth of Trifolium repens as influenced by seasonal changes in the light environment. Journal of ecology 50: 449-459.

Brougham, R.W.; Candler, W.; Wright, A. 1963. Small farm experiments. Discussion paper. Dept. Agric. Econ. Farm Mgmt., Massey University College 11: 1-16. 
Brougham, R.W. 1964. Some factors influencing the grass-legume balance in grazed pasture. Proceedings of the $X$ International Botanical Congress (publication not seen).

Brougham, R.W. 1965a. The effects of red clover on the leaf growth of white clover under long spelling during summer. New Zealandjournal ofagricultural research 8: 859-864.

Brougham, R.W. 1965b. Research requirements of North and South Island Hill Country. Proceedings of the Biennial Conference New Zealand Assoc. Soil Conservators 1965: (publication not seen).

Brougham, R.W. 1966a. Aspects of light utilisation, leaf development and senescence and grazing on grass-legume balance and the productivity of pastures. Proceedings of the New Zealand Ecol. Soc. 13: 58-65.

Brougham, R.W.1966b. Pasture management for high production. Dairyfarming Annual 1966: 99-1 10.

Brougham, R.W. 1966c. Potential of present type pastures for livestock feeding. New Zealand Agricultural Science 2(2): 19-22.

Brougham, R.W.; Glenday, A.C. 1967. Grass growth in mid-summer: a re-interpretation of published data. Journal of theBritish Grassland Society 22: 100107.

Brougham, R. W.; Harris, W. 1967. Rapidity and extent of changes in genotypic structure induced by grazing in a ryegrass population. New Zealand journal of agricultural research 10: 56-65.

Broughām, R.W.1968. Some limiting factors to pastüre production. Proceedings of the Australian Grassland Association 1968: 225-246.

Brougham, R.W. 1969. Some aspects of pasture production and management. Dairyfarming Annual 1969: 17-22.

Brougham, R.W.; Glenday, A.C. 1969. Weather fluctuations and the daily rate of growth of pure stands of three grass species. New Zealand journal of agricultural research 12: 125-1 36.

Brougham, R.W. 1970a. Present position of pasture establishment research in New Zealand. Proceedings of the New Zealand Grassland Association 31: 127134.

Brougham, R.W. 1970b. The approach to grassland as a soil-plant-animal system-agricultural research farming practice. Proceedingsof the XI International Grassland Congress A: 120-126.

Brougham, R.W. 1971a. Presidential address. Proceedings of the New Zealand Grassland Association 32: 4-10.

Brougham, R.W. 1971b. Frequency and intensity of grazing and their effects on pasture production. Proceedings of the New Zealand Grassland
Association 32: 137-144.

Brougham, R.W. 1973a. Pasture management and production. Proceedings of the Ruakura Farmers' Conference 1973: 169-1 83.

Brougham, R.W. 1973b. Pasture management and production. Sheepfarming Annual 1973: 31-39.

Brougham, R.W. 1974. New pasture varieties in New Zealand grassland farming. Proceedings of the Lincoln College Farmers' Conference 1974: 6-15.

Brougham, R.W.; Jackman, R.H. 1974. Clover nitrogen and pasture management. Massey University Dairyfarming Annual 1974: 38-47.

Brougham, R.W.; Grant; D.A.; Goodall, V.C. 1974 The occurrence of browntop in the Manawatu. Proceedings of the New Zealand Grassland Association 35(1): 86-94.

Brougham, R.W.; Causley, D.C.; Madgwick, L.E. 1975. Pasture management systems and animal production. Proceedings of the Ruakura Farmers.' Conference 1975: 65-69.

Brougham, R. W. 1977a. Maximising animal production from temperate grassland. Proceedings of the International Mtg Animal Production from Temperate Grassland. Dublin, June 1977: 140-1 46.

Brougham, R.W. 1977b. Some aspects of pasture development and management in New Zealand. Proceedings of the New Zealand Grassland Association 38: 38-46.

Brougham, R.W.; Grant, D.A. 1977. Hill country farming in New Zealand - an overview. Proceedings of the -of -the--International-Hill-land-Symposium;Morgantown, W, Virginia, 1976 (publication not seen).

Brougham, R.W. 1978a. Some trends in grassland farming in Europe. Proceedings of the New Zealand Grassland Association 39: 5-19.

Brougham, R.W. 1978b. Thegrasslands of New Zealand: an overview. Proceedings of the 2nd Australasian Conference Grassland Invertebrate Ecology. Palmerston North, New Zealand: 16-23.

Brougham, R.W. 1978c. Director's report. Grasslands Division Research Report 1978. Department of Scientific and Industrial Research Information Series 132: 5-7.

Brougham, R.W.; Ball, P.R.: Williams, W.M. 1978. The ecology and management of white clover-based pastures. pp. 309-324. In: Wilson, J.R. (ed.). Plant Relations in Pastures, East Melbourne: CSIRO.

Brougham, R.W. 1979. Grassland Memorial Trust Address. Proceedings of the New Zealand Grassland Association 40: 5-16.

Brougham, R.W. 1980. The naming of 'Grasslands' pasture cultivars and pipeline selections. New Zealand Agricultural Science 14: 127-128. 
Brougham, R.W.; Bali, P.R. 1980. Nitrogen relationships in pastoral agriculture and prospects for use of bag nitrogen in dairyfarming. Proceedings of the Large Herds Conference, Thames (publication not seen).

Brougham, R.W. 1981. Pasture management animal production. Proceedings of the New Zealand Grassland Association 42: 54-69.

Brougham, R.W. 1981 b. Director's report. Grasslands Division Research Report 1980. Department of Scientific and Industrial Research Information Series 151: 5.

Brougham, R.W. 1982a. Grassland farming in New Zealand. Proceedings of the 7th Friesian Breeders Conference Christchurch, (publication not seen).

Brougham, R.W. 1982b. Director's report. Grasslands Division Research Report 1982. Grasslands Division DSIR Publication: 5.

Brougham, R.W. 1983. Practical livestock - forage systems: Model to manager. Proceedings of the XIV International Grassland Congress: 48-55.

Brougham, R.W. 1984a. Pasture development in New Zealand with emphasis on beef production. 9th World Hereford Cattle Breeders Congress (publication not seen).

Brougham, R.W. 1984b. Director's report. Grasslands Division Research Report 1984. Grasslands Division DSIR Publication: 5-6.

Barnes, R.F.; Ball, P.R.; Brougham, R.W., Marten, G.C.; Minson, D.J. 1985. Forage legumes for energyefficient animal production. Proceedings of the Trilateral Workshop, Palmerston North, New Zealand. USDA-ARS, New Orleans, LA 70719, USA. $323 \mathrm{pp}$.

Brougham, R.W.; Cosgrove, G.P. 1985. Pastures and pasture management for high animal production in New Zealand. Proceedings of the XV International Grassland Congress: 1134-1 136.

Brougham, R.W. 1986a. Editorial. Welcome to New Zealand Turf Management Journal. New Zealand turf management journal I(1): 3 .

Brougham, R.W. 1986b. Editorial. New Zealand turf management journal l(2): 3 .

Brougham, R.W. 1987a. Editorial. New Zealand turf management journal l(4): 3 .

Brougham, R.W. 1987b. Editorial. The Turf Culture Institute. New Zealand turf management journal $l(6): 3$.

Brougham, R.W. 1988a. Editorial. New Zealand turf management journal 2(2): 3 .

Brougham, R.W. 1988b. Editorial. Thechallenges ahead. New Zealand turf management journal 2(4): 3.

Brougham, R.W. 1989a. Editorial. New Zealand turf management journal 3(2): 3 .

Brougham, R.W. 1989b. Editorial. New Zealand turf management journal 3(3): 3 .

Brougham, R.W. 1990a. Editorial. New Zealand turf management journal 4(1): 3 .

Brougham, R.W. 1990b. Bowls - Brazilian style. New Zealand turf management journal 4(1): 23-24.

Brougham, R.W. 1990c. Something different, New Zealand turf management journal 4(2): 16.

Brougham, R.W. 1990d. Something different. New Zealand turf management journal 4(3): 16.

Brougham, R.W. 1990e. Editorial. New Zealand turf management journal 4(4): 3 .

Brougham, R.W. 1990f. Something different - Lords, Highbury and Twickenham. New Zealand turf management journal 4(4): 17-19.

Brougham, R.W. 1991a. Something different - golf course management and the Turf Culture Institute. New Zealand turf management journal 5(1): 14-15.

Brougham, R.W. 1991b. Something different - turf development in China. New Zealand turf management journal 5(4): 24-25.

Brougham, R.W. 1992. Something different - some turf developments in Japan. New Zealand turf management journal 6(3): 27-28.

Brougham, R.W. 1993a. Croke Park, Dublin - an emerald green turf of Poa trivialis. New Zealand turf management journal 7(4): 24.

Brougham, R.W. 1993b. Presidential address. Proceedings of the XVII International Grassland Congress I: 1-2.

Clark, D.A.; Brougham, R.W. 1979. Feed intake of grazing friesian bulls. Proceedings of the New Zealand Society of Animal Production 39: 265274.

Clark, D.A.; Causley, D.C.; Brougham, R.W. 1979. Nitrogen fixation in pasture. VI. Manawatu Plains, Kairanga. New Zealand journal of experimental agriculture 7: 23-25.

Cosgrove, G.P.; Brougham, R.W. 1985. Grazing influences on ryegrass and red clover in a mixture. Proceedings of the New Zealand Grassland Association 46: 71-76.

Cosgrove, G.P.; Brougham, R.W. 1988. Pasture strategies for dairy beef production. Proceedings of the New Zealand Grassland Association 49: 5762.

Crush, J.R.; Cosgrove, G.P.; Brougham, R.W. 1982. The effect of nitrogen fertiliser on clover nitrogen fixation in an intensively grazed Manawatu pasture. New Zealand journal of experimental agriculture 10: 395-401.

Crush, J.R.; Cosgrove, G.P.; Brougham, R.W. 1983. Nitrogen fixation during 1979-81 in two pastures on the Manawatu Plains. New Zealand journal of experimental agriculture 11: 17-20. 
Flux, D.S.; Butler, G.W.; Rae, A.L.; Brougham, R.W. 1960. Relationship between levels of Iodine and cyanogenetic glucoside in pasture and the productive performance of sheep. Journal of agricultural science, Cambridge 55: 191-1 96.

Harris, W.; Brougham, R.W. 1968. Some factors affecting change in botanical composition in a ryegrass-white clover pasture under continuous grazing. New Zealand journal of agricultural research II: $15-38$.

Harris, W.; Brougham, R.W. 1970. The effect of grazing on the persistence of genotypes in a ryegrass population. New Zealand journal of agricultural research 13: 263-278.

Hay, R.J.M.; Brougham, R.W.: Harris, A.J. 1979. The importance of rotational grazing of pasture for intensive animal production in New Zealand. Grass andforage science 34: 62-63.

Hunt, L.A.; Brougham, R.W. 1966. Some aspects of growth in an undefoliated stand of Italian Ryegrass. Journal of applied ecology 3: 21-28.

Hunt, L.A.: Brougham, R.W. 1967. Some changes in the structure of a perennial ryegrass-white clover sward frequently but leniently grazed during the summer. New Zealand journal of agricultural research 10: 397-404.

Marten, G.C.; Matches, A.G.; Barnes, R.F.; Brougham, R.W.; Clements, R.J.; Sheath, G.W. 1989. Proceedings of the Trilateral Workshop, Honolulu, Hawaii. Madison, Wisconsin, USA; American Society of Agronomy, Crop Science Society of America, Soil Science Society of America USDAARS, University of Minnesota, St Paul, MN 55101, USA. 572 pp.

Rae, A.L.; Brougham, R.W.; Glenday, A.C.; Butler, G.W. 1963. Pasture type in relation to live-weight gain, carcass composition, iodine nutrition and some rumen characteristics of sheep. Journal of agricultural science, Cambridge 61: 187-190.

Rae, A.L.;Brougham, R.W.; Barton, R.A. 1964: A note on live-weight gains of sheep grazing different ryegrass pastures. New Zealand journal of agricultural research 7: 491-495.

Scott, D.; Menalda, P.H.; Brougham, R.W. 1968. Spectral analysis of radiation transmitted and reflected by different radiations. New Zealand journal of botany 6: 427-449.

Sears, P.D.; Brougham, R.W. 1964. Symposium on Grasslands Division's new ryegrass 1. Establishment trials on ryegrass and clover mixtures. Proceedings of the New Zealand Grassland Association 25: 128136.

Vartha, E.W.; Brougham, R.W. 1975: Experimentation involving variable grazing pressure in fixed stocking rate systems: examples from New Zealand. Proceedings of the American Society of Agronomy $V V$ : (publication not seen).

\section{Other references cited in the review}

Anslow, R.C. 1965. Grass growth in midsummer. Journal of the British Grassland Society 20:19-26.

Atkinson, J.D. 1976. DSIR'S First Fifty Years. Government Printer, Wellington.

Brown, K.R.; Evans, P.S. 1973. Animal treading. A review of the work of the late D. B. Edmond. New Zealand journal of experimental agriculture 1: 2 17216.

Corkill, L. 1945. Short rotation ryegrass, its breeding and characteristics. New Zealand journal of agriculture 71: 465-468.

Donald, C.M. 1956. Competition among pasture plants. Proceedings of the VII International Grassland Congress: 80-91.

Forde, M.B.; Suckling, F.E.T. 1980. Genetic resources in high-rainfall pastures of New Zealand 11. Description of the ryegrass collection. New Zealand journal of agricultural research 23: 179-1 89.

Glenday, A.C. 1953. The statistician and pasture trials. Proceedings of the New Zealand Grassland Association 14: 21 l-220.

Glenday, A.C. 1955. The mathematical separation of plant and weather effects in field growth studies.

- Australian-journal-of-agricultural research 6: 813822.

Glenday, A.C. 1959. Mathematical analysis of growth curves replicated in time. New Zealand journal of agricultural research 2: 297-305.

Grant, D.A.: Lambert, M.G. 1979. Nitrogen fixation in pasture V. Unimproved North Island hill country, "Ballantrae'. New Zealandjournal of experimental agriculture 7: 19-22.

Grasslands Division. 1978a. Grasslands Division Research Report 1978. Department of Scientific and Indūstriāl-Research-Information-Series-132: $1=80$.

Grasslands Division. 1978b. Popular summaries of research papers 1974 to 1978. Grasslands Division. DSIR: $1-47$.

Grasslands Division. 1980a. Grasslands Division Research Report 1980. Department of Scientific and Industrial Research Information Series 151: l-80.

Grasslands Division. 1980b. Popular summaries of research papers 1979 to 1980. Grasslands Division. DSIR: $l-40$.

Grasslands Division. 1982a. Grasslands Division Research Report 1982. Grasslands Division Publication: 1-79.

Grasslands Division. 1982b. Popular summaries of 
research papers 1981 to 1982. Grasslands Division. DSIR: $\mathbf{l - 4 8}$.

Grasslands Division. 1984. Grasslands Division Research Report 1984. Grasslands Division Publication: I-74,

Harris, W. 1973. Why browntop is bent on creeping. Proceedings of the New Zealand Grassland Association 35: 101-109.

Harris, W.; Pitieiro, J.; Henderson, J.D. 1980. Performance of mixtures of ryegrass cultivars and prairie grass with red clover cultivars under two grazing frequencies. III. Herbage production and shoot numbers in the second year. New Zealand journal of agricultural research 23: 339-348.

Harris, W.; Kunelius, H.T. 1988. Production of pastures in the second year after drilling of red clover and ryegrass. New Zealand journal of experimental agriculture 16: 17-20.

Harris, W.; Thomas, V.J. 1970. Competition among pasture plants I. Effects of frequency and height of cutting on competition between two ryegrass cultivars. New Zealand journal of agricultural research 13: 833-861.

Hunt, W.F. 1970. The influence of leaf death on the rate of accumulation of green herbage during pasture regrowth. Journal of applied ecology 7: 41-50.

Hunt, W.F. 1971. Leaf death and decomposition during pasture regrowth. New Zealand journal of agricultural research 14: 208-218.

Korte, C.J.; Harris, W. 1987: Effects of grazing and cutting. pp. 71-79. In: Snaydon, R.W. (ed.). Ecosystems of the world 17B. Managed grasslands. Analytical Studies. Amsterdam, The Netherlands: Elesvier Science Publishers B.V.

Kunelius, H.T.; Harris, W.; Henderson, J.D.; Baker. C.J. 1982. Comparison of tillage methods on red clover and ryegrass establishment and production under grazing in the establishment year. New Zealand journal of experimental agriculture 10: 253-263.

Lambert, M.G.; Clark, D.A., Grant, D.A.; Costall, D.A. 1983. Influence of fertiliser and grazing management on North Island moist hill country. 1. Herbage accumulation. New Zeafandjoumal of agricultural research 26: 95-108.

Lancashire, J.A.; Keogh, R.G. 1966a. Some observations on an outbreak of hogget ill-thrift. New Zealand journal ofagricultural research 9: 916-924.

Lancashire, J.A.: Keogh, R.G. 1966b. Some aspects of the behaviour of grazing sheep. Proceedings of the New Zealand Society of Animal Production 26: 2235 .

Leafe E.L.; Stiles, W.; Dickinson, S.E. 1974. Physiological processes influencing the pattern of productivity of intensively managed grass sward. Proceedings of the XII International Grassland Congress: 442-457.

Levy, E.B. 1970. Grasslands of New Zealand. Third edition. Wellington: Government Printer.

Melville, J.; Sears, P.D. 1953. Pasture growth and soil fertility II. the influence of red and white clovers, superphosphate, lime, and dung and urine on the chemical composition of pasture. New Zealand journal of science and technology A35: Supp. 1, $30-41$.

Mitchell, K.J. 19.53: Growth habits of short rotation and perennial ryegrass.Proceedings of the New Zealand Grassland Association 14: 164-1 71.

Piñeiro, J.; Harris, W. 1978a. Performance of mixtures of ryegrass cultivars and prairie grass with red clover cultivars under two grazing frequencies. I. Herbage production in the establishment year. New Zealand journal of agricultural research 21: 83-92.

Pitieiro, J.; Harris, W., 1978b. Performance of mixtures of ryegrass cultivars and prairie grass with red clover cultivars under two grazing frequencies. II. Shoot populations and natural reseeding of prairie grass. New Zealand journal of agricultural research 21: 665-673.

Sears, P.D. 1953a. Pasture growth and soil fertility I. The influence of red and white clovers, superphosphate, lime and sheep grazing, on pasture yields and botanical composition. New Zeafandjoumaf of science and technology A35: Supp. 1, 1-30.

Sears, P.D. 1953b. Pasture growth and soil fertility IV. The influence on soil fertility of clovers, superphosphate, lime, dung and urine applied to the pastures, as measured by the growth of subsequent forage crops. New Zealand journal of science and technology A35: Supp. 1, 53-67.

Sears, P.D.; Evans, L.T. 1953. Pasture growth and soil fertility III. The influence of red and white clovers, superphosphate, lime, and dung and urine on soil composition, and on earthworm and grass-grub populations. New Zealand journal of science and technology A35: Supp. 1, 42-52.

Sears, P.D. 1953c. Pasture growth and soil fertility V. The effect of nitrogenous fertilisers, and of "day" and "night" grazing. New Zealand journal of science and technology A35: Supp. 1, 68-77.

Sears, P.D.; Hyde, E.O.C.; Greenwood, R.M. 1955. Pasture establishment on pumice soils. New Zeafand journal of science and technology A37: 11 0-1 40.

Suckling, F.E.T.; Forde, M.B. 1978. Genetic resources in high-rainfall pastures of New Zealand I. Collection of ryegrass, browntop and white clover. New Zealand journal of agricultural research 21: 499-508. 